\title{
Channel morphology and bed-load yield in fluvial, formerly-glaciated headwater streams of the Columbia Mountains, Canada
}

\author{
K.C. Green ${ }^{\text {a,* }}$, F. Brardinoni ${ }^{b}$, Y. Alila ${ }^{\text {a }}$ \\ a Department of Forest Resource Management, University of British Columbia, Vancouver, Canada \\ b Department of Geological Sciences, University of Milano-Bicocca, Milano, Italy
}

\section{A R T I C L E I N F O}

Article history:

Received 14 November 2011

Received in revised form 12 April 2012

Accepted 4 May 2012

Available online 11 May 2012

\section{Keywords:}

Fluvial sediment transfer

Snowmelt hydrology

Channel morphology

Armor layer

Bedload yield

Glaciated topography

\begin{abstract}
A B S T R A C T
This study examines channel-reach morphology and bedload yield dynamics in relation to landscape structure and snowmelt hydrology in headwater streams of the Columbia Mountains, Canada. Data collection relies on field surveys and geographic information systems analysis in conjunction with a nested monitoring network of water discharge and bedload transfer. The landscape is characterized by subdued, formerlyglaciated upland topography in which the geomorphic significance of landslides and debris flows is negligible and fluvial processes prevail. While the spatial organization of channel morphology is chiefly controlled by glacially imposed local slope in conjunction with wood abundance and availability of glacigenic deposits, downstream patterns of the coarse grain-size fraction, bankfull width, bankfull depth, and stream power are all insensitive to systematic changes of local slope along the typically stepped long profiles. This is an indication that these alluvial systems have adjusted to the contemporary snowmelt-driven water and sediment transport regimes, and as such are able to compensate for the glacially-imposed boundary conditions. Bedload specific yield increases with drainage area suggesting that fluvial re-mobilization of glacial and paraglacial deposits dominate the sedimentary dynamics of basins as small as $2 \mathrm{~km}^{2}$. Stepwise multiple regression analysis shows that annual rates of sediment transfer are mainly controlled by the number of peak events over threshold discharge. During such events, repeated destabilization of channel bed armoring and re-mobilization of sediment temporarily stored behind LWD structures can generate bedload transport across the entire snowmelt season. In particular, channel morphology controls the variability of bedload response to hydrologic forcing. In the present case studies, we show that the observed spatial variability in annual bedload yield appears to be modulated by inter-basin differences in morphometric characteristics, among which slope aspect plays a critical part.
\end{abstract}

(c) 2012 Elsevier B.V. All rights reserved.

\section{Introduction}

Steep headwater streams are a distinct class of channels with characteristic morphologies, processes, and dynamics (Gomi et al., 2002; Hassan et al., 2005). They constitute the outermost, steeper portion of the drainage network that conveys sediment and wood fluxes from hillslopes to high-order streams. In headwater streams, colluvial and fluvial processes coexist, consequently, the magnitude and frequency of sediment and wood inputs operated by mass wasting exert a primary control on channel morphology (Grant et al., 1990; Benda and Dunne, 1997) and bedload transport (Gomi and Sidle, 2003).

The spatial distribution of channel-reach morphology has been explained as the expression of the relative interaction between sediment supply and transport capacity (Montgomery and Buffington,

\footnotetext{
* Corresponding author. Tel.: +1 604822 6058; fax: +1 6048229106.

E-mail addresses: apexgeo.kg@gmail.com (KC. Green), francesco.brardinoni@unimib.it (F. Brardinoni).
}

1997, 1998). In this regard, the downstream progression of channel types along a concave-up longitudinal profile reflects a general shift from supply-limited conditions (colluvial reaches, boulder-cascades, and step-pools) to transport-limited ones (riffle-pools), with increasing opportunities for in-channel storage (Church, 1992).

In high-energy headwater streams the movement of bedload material, the sediment fraction that builds channel architecture, exhibits high spatial and temporal variability in relation to peak flow, the history of mass-wasting activity, and in-channel storage conditions (Gomi and Sidle, 2003). Seasonal variations in bedload yield have been explained with episodic sediment inputs from adjacent hillslopes and from LWD structures (Lisle, 1986; Gintz et al., 1996; Gomi and Sidle, 2003). For example, the latter authors show how the typical exhaustion-like seasonal pattern of bedload (clockwise hysteresis) associated with the maximum annual flood can be reversed (counter-clockwise hysteresis) locally by landslide sediment supply. Short-term bedload transport variations in mountain streams are usually associated with the break-up and subsequent re-establishment of the bed armor layer (Gomi and Sidle, 2003; Hassan et al., 2005). 
Although important progress has been made in understanding the hydro-geomorphology of humid, steep headwater channels, in mountain environments headwater streams are not necessarily synonymous with mass-wasting dominated systems. In fact, large portions of tectonically-active and inactive orogens exhibit hydro-climatic (e.g., continental) and topographic boundary conditions (e.g., plateau-like topography) that do not favor a sediment transport regime dominated by rapid shallow failures. For example, in British Columbia fluviallydominated headwater streams drain over $30 \%$ of the Canadian Cordillera, including the Interior Plateau and portions of the Columbia Mountains and Rocky Mountains (Holland, 1964).

This typology of headwater systems, which has been largely neglected, may present unique morphodynamics. An understanding of their hydro-geomorphic functioning is fundamental for addressing problems of forest management, landscape evolution, aquatic ecology, and conservation biology. To our knowledge no study has examined fluvially-dominated headwater streams considering both morphological and sediment transport aspects. This paper reports one of the first comprehensive accounts on headwater streams in which mass wasting disturbance is not prevalent.

The objectives of this paper are to (1) examine the spatial variability of channel-reach morphology and cross-sectional channel variates at the watershed scale, (2) evaluate bedload sediment dynamics in relation to hydrologic variability, (3) elucidate linkages between channel morphology and bedload transport, and (4) evaluate the effects of topographic and sedimentary glacial imprints on channel morphodynamics. We pursue these objectives through an experimental set up that relies on a nested network of hydrologic stations and in-channel sediment traps in Cotton Creek, a forested, fluvially-dominated watershed of the southern Columbia Mountains, Canada.

\section{Study area}

Cotton Creek (22.1 km², Fig. 1a), is a forested, mountain basin of the Purcell Range, Columbia Mountains physiographic region, British Columbia (Holland, 1964). Elevation ranges from $900 \mathrm{~m}$ a.s.l. in proximity of Moyie Valley floor, to $2018 \mathrm{~m}$ along the south-eastern divide of the basin. Channel gradient in the basin, ranging between 3 and 40\%, does not support debris-flow initiation. Our observations are consistent with findings from prior work conducted in neighboring Selkirk and Monashee Ranges of the Columbia Mountains, according to which landslide and debris-flow initiation is rare on slopes at $<47 \%$ (Jordan, 2002).

The drainage network has a dendritic pattern consisting of two main tributaries: Elk Creek $\left(5.7 \mathrm{~km}^{2}\right)$ and Upper Cotton Creek $\left(10.3 \mathrm{~km}^{2}\right)$. The former, in comparison to Upper Cotton Creek, is characterized by lower elevation (Fig. 2a), and lower slope (Fig. 2b). With respect to aspect, Elk exhibits a comparatively greater proportion of terrain facing south (i.e., S, SE, and SW; Fig. 2c) at the expense of north-facing topography (i.e., $\mathrm{N}$ and $\mathrm{NE}$ ). Dominantly south-facing slopes imply higher incoming solar radiation, hence faster snowmelt runoff. As a result, a substantial portion of Elk Creek basin is snow free at least 2 weeks earlier than Upper Cotton Creek (Jost et al., 2007).

The area is underlain by middle Proterozoic meta-sedimentary rocks of the Purcell Group. Silty-sandy, compact, matrix-supported basal till is the dominant surficial material in Cotton Creek and blankets much of the catchment from the lower elevations up to the ridge crests (Fig. 1b). More loosely consolidated, gravelly ablation till is present as veneers and blankets the northern slopes of the watershed above about $1500 \mathrm{~m}$. Sandy, gravelly glaciofluvial deposits with relict meltwater channels occur in association with the ablation till.

At the peak of the last glacial period Cotton Creek was overridden by the Cordilleran Ice sheet that extended south-westward into the Moyie Valley from the Rocky Mountain Trench (Clague et al., 1980). Relict glacial topography suggests that shallow valley-side glaciers descended westward and northward coalescing in Cotton Creek valley before flowing into the main Moyie Valley glacier. Surficial material

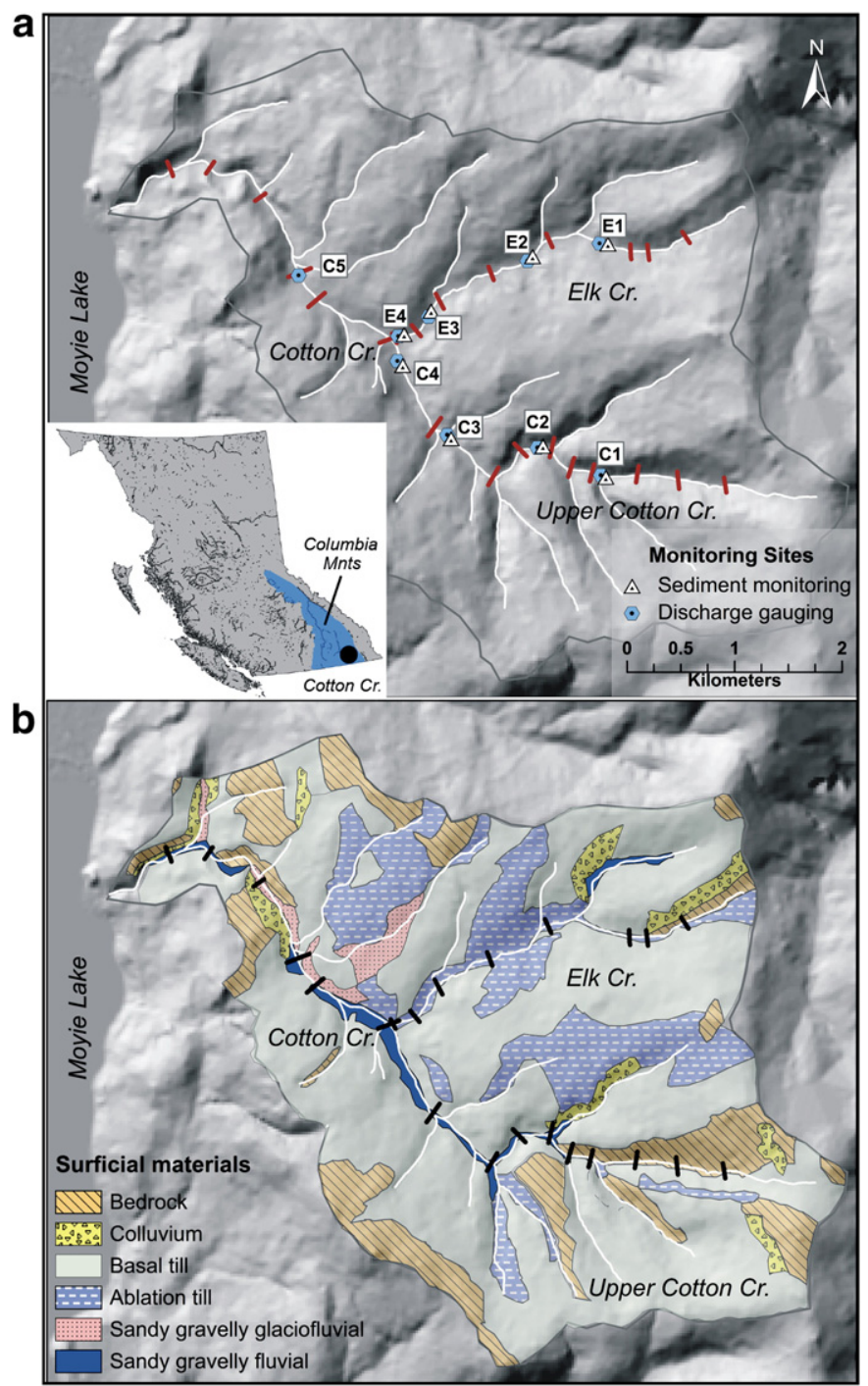

Fig. 1. Maps of the Cotton Creek basin showing (a) the shaded relief with the locations of reach breaks (red breaks) and monitoring stations; and (b) the distribution of the surficial materials. Terrain mapping complies with British Columbia Terrain Stability TSIL C survey level (Howes and Kenk, 1997) and as such entailed ground truthing in $50 \%$ of the polygons.

mapping (Fig. 1b) indicates that tributaries of both Upper Cotton and Elk contained pro-glacial deposits (e.g., glaciofluvial deposits, Fig. 1b) suggesting that these drainages were ice-free while the surface of the Cordilleran Ice Sheet occupying the Rocky Mountain Trench was still above the highest ridge tops (Ryder, 1981; Jackson and Clague, 1991; Ryder et al., 1991). Glaciofluvial and ablation deposits have been reworked and deposited as paraglacial fluvial deposits (Fig. 1b) along the length of Upper Cotton and Cotton Creek (below Elk confluence). A small kame terrace (identified as glaciofluvial, Fig. 1b) along the lower reaches of Cotton Creek likely marks the elevation of the ice surface in the Moyie Valley directly to the west that persisted while pro-glacial meltwater streams were flowing out of the tributary valleys.

Today the region has a continental climate. Precipitation $(600 \mathrm{~mm}$ annually) falls mainly as snow between October and March. An average maximum snow accumulation of $400 \mathrm{~mm}$ (snow water equivalent), measured on April 1st since 1971, is reported at the Moyie Mountain snow pillow ( $1840 \mathrm{~m}$ a.s.l; B.C. Ministry of Environment) located $7 \mathrm{~km}$ south of Cotton Creek. Stream flows in the southern Purcell Mountains rise rapidly in mid April to mid May in response to solar- 

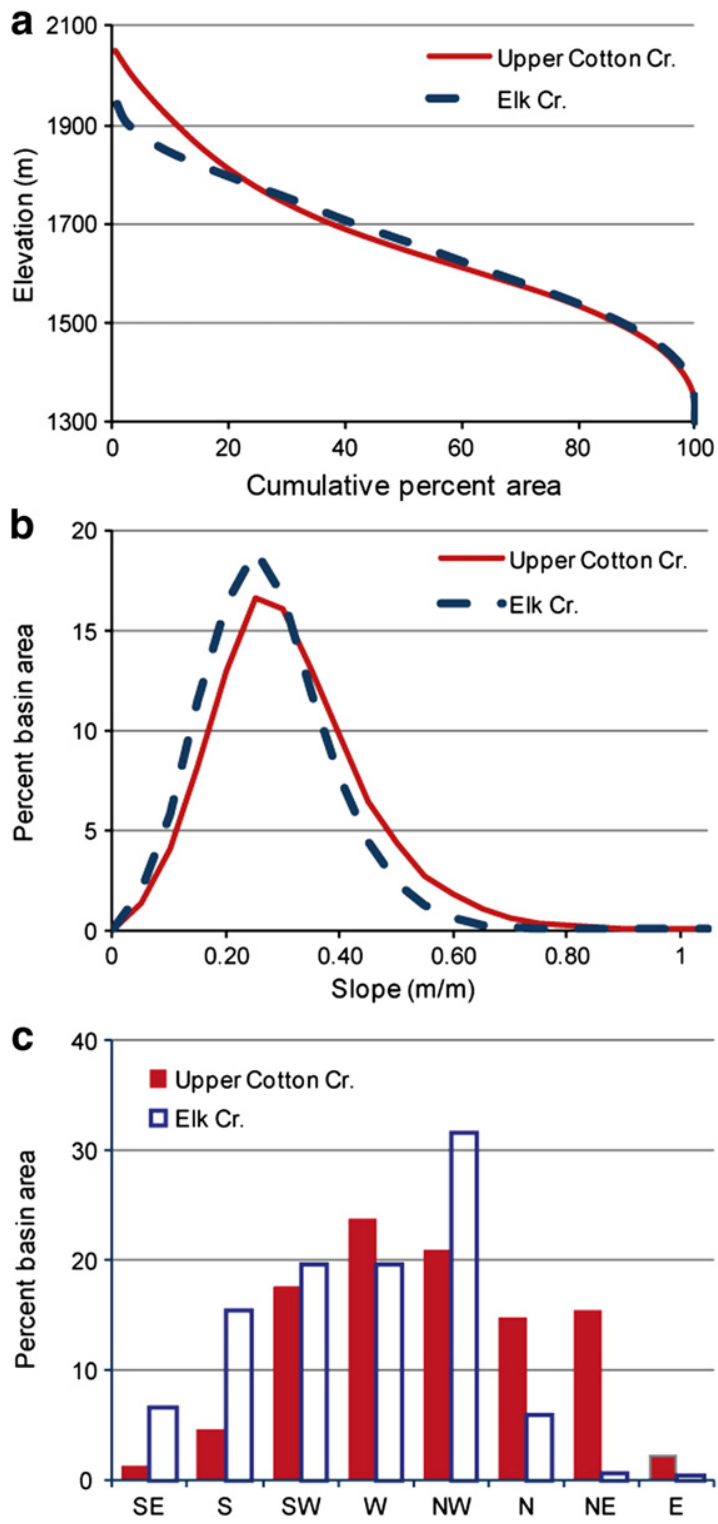

Fig. 2. Elk Creek and Upper Cotton Creek topographic characteristics: (a) hypsometric curves; (b) slope frequency distributions; and (c) aspect frequency distributions.

radiation driven snowmelt and remain elevated above base flows into mid July. Typically there are between two and five independent discharge peaks lasting from 2 to 7 days during the spring snowmelt freshet in response to periods of warm, sunny weather.

Vegetation within the watershed consists of 60 to 70 year old naturally regenerated mixed conifer stands. Starting from the mid 1990s, timber harvesting has affected respectively $34 \%$ and $20 \%$ of lower-tomid slopes in Elk Creek and Upper Cotton Creek. Riparian buffers along the drainage network have protected the channel banks and adjacent flood plain from logging disturbance, so that anthropogenic effects on sediment and wood delivery to streams are regarded as minimal.

\section{Data collection and methods}

Data collection combines aerial photo interpretation (API), GIS analysis, field surveys, and the installation of water and sediment monitoring stations. API served for identifying major landscape structures and sediment sources. GIS analyses were instrumental to extract longitudinal profiles (Fig. 3a), calculate drainage area, hence to build area-slope plots
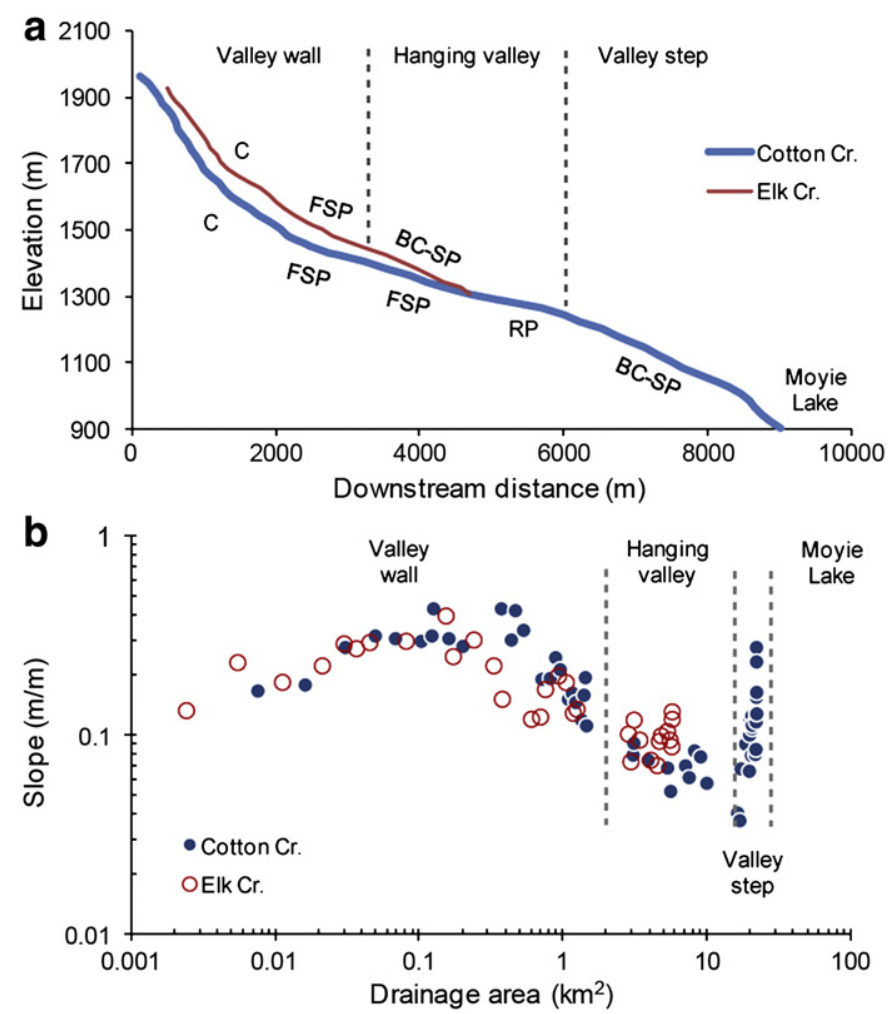

Fig. 3. (a) Longitudinal profiles, and (b) area-slope plot. For explanation of the channel morphologies (abbreviated on profile) see text.

(Fig. 3b) from a 25-m digital elevation model (Montgomery and Foufoula-Georgiou, 1993). Mapping of the surficial materials was conducted via fieldwork and API following the British Columbia Terrain Classification System (Howes and Kenk, 1997). Specifically, 50\% of the terrain polygons delineated through API were field-checked to confirm distribution and characteristics of surficial materials.

Intensive field surveys along the study channel network $(10.7 \mathrm{~km})$ entailed delineation of 23 channel reaches according to the degree of hillslope-channel coupling and dominant channel bed morphology, as well as measurement of the quantitative morphometric variables that control and best summarize channel morphodynamics (Church, 1992, 2006; Montgomery and Buffington, 1998). Channel bed morphology in the study basin includes colluvial (C), boulder-cascade (BC), forced step-pool (FSP), step-pool (SP), and riffle-pool (RP) reaches. Examples of channel types found in Upper Cotton Creek and Elk Creek are provided in Fig. 4.

Field-based channel data include local slope (S), bankfull width (w), bankfull (thalweg) depth (d), largest actively mobile particle diameter $\left(D_{\max }\right)$, and number and height of functioning large woody debris (LWD) pieces. Channel slope was measured with a theodolite and stadia rod. Bankfull width and the intermediate axis of the five largest stones (here referred as $D_{\max }$ ) were measured with a metric tape; depth measurements at bankfull were taken with a metric rod along the thalweg. Bankfull level was measured as the transition between vegetation types indicative of partially saturated (e.g., grasses, horsetail, and moss) and fully saturated (e.g., moss only) soil moisture conditions, as well as by physical marks on the vegetated channel banks indicative of repeated scour by flood flows (e.g., Wohl and Wilcox, 2005).

Depending on channel accessibility (i.e., obstructions associated with LWD pieces), field measurements were taken at a length scale equal to 2-10 times the local channel width, and then averaged (weighted by distance) across reaches. Channel reach lengths spanned between 50 and 100 channel widths. $D_{\max }$ is meant to represent a 

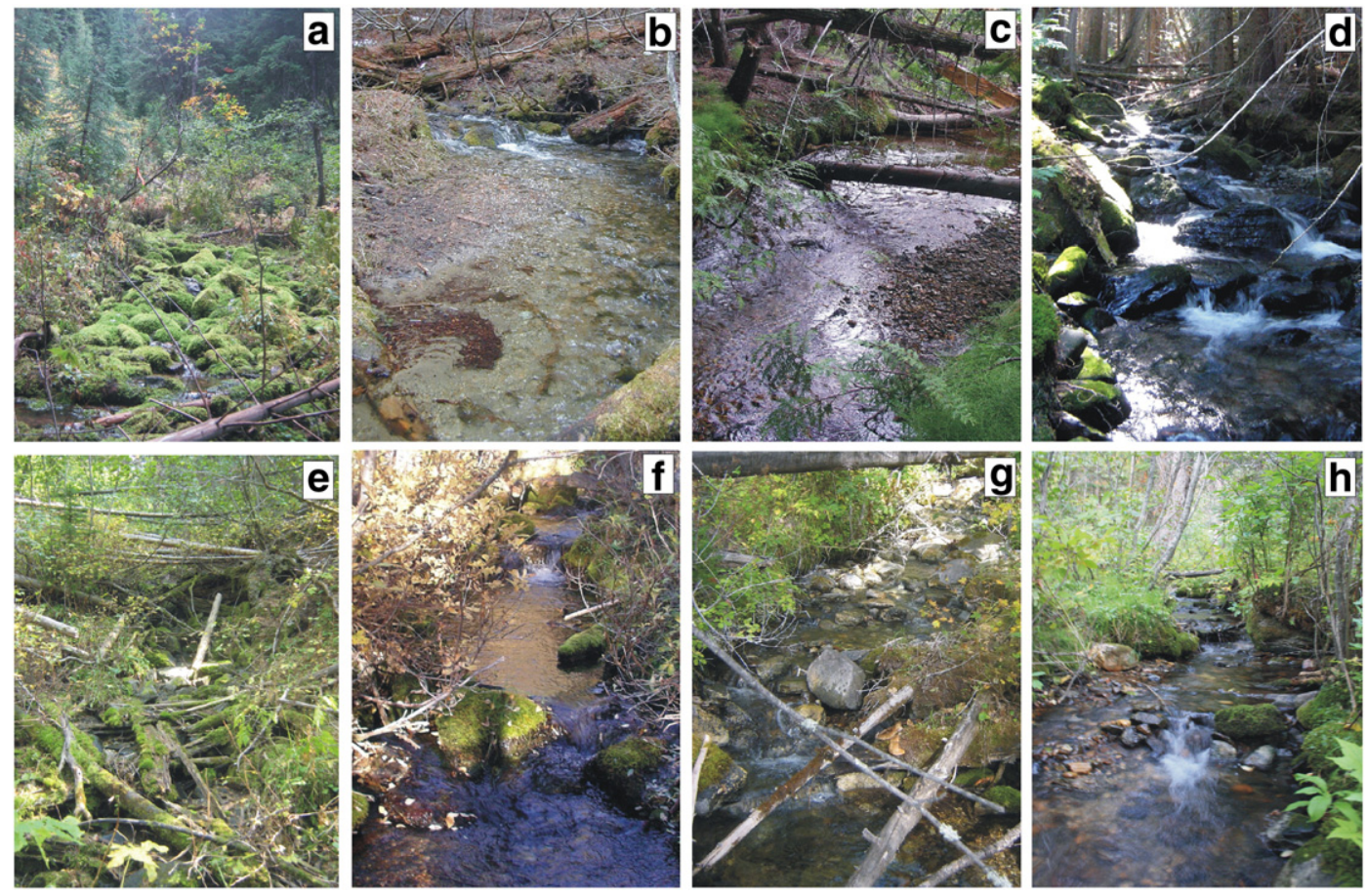

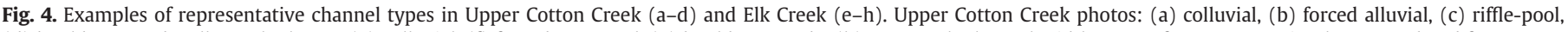

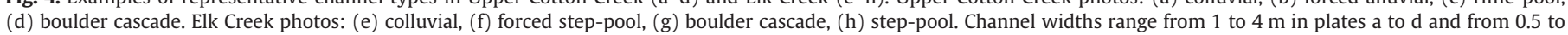
$2 \mathrm{~m}$ in plates e to $\mathrm{f}$.

proxy for first-order bed roughness, insensitive to exceptionally large boulders. Given the foregoing specifications, surface $D_{\max }$ for one reach is estimated from 30 to 60 stones collected within the active channel bed. To assess $D_{\max }$ reliability we conducted Wolman pebble counts in 13 reaches. Results indicate that $D_{\max }$ corresponds, on average, to $\mathrm{D}_{88}$ of the channel bed surface and displays a relatively narrow range of variability (i.e., $\mathrm{D}_{83}-\mathrm{D}_{95}$ ) (Fig. 5).

Sediment yield was monitored using a nested network of channel spanning traps and removable pit traps (Fig. 1a) over 3 to 4 snowmelt freshets at 8 locations along the channel network (Table 1). In, 2005, the initial year of instrumentation, the sediment monitoring network included one headwater weir on Elk Creek (E1) and two channel spanning pit traps in the lowest reaches of Upper Cotton and Elk Creeks (E4 and C4). During this start-up year sediment monitoring was limited to total yield (Table 1). In 2006 and 2007 the monitoring network was

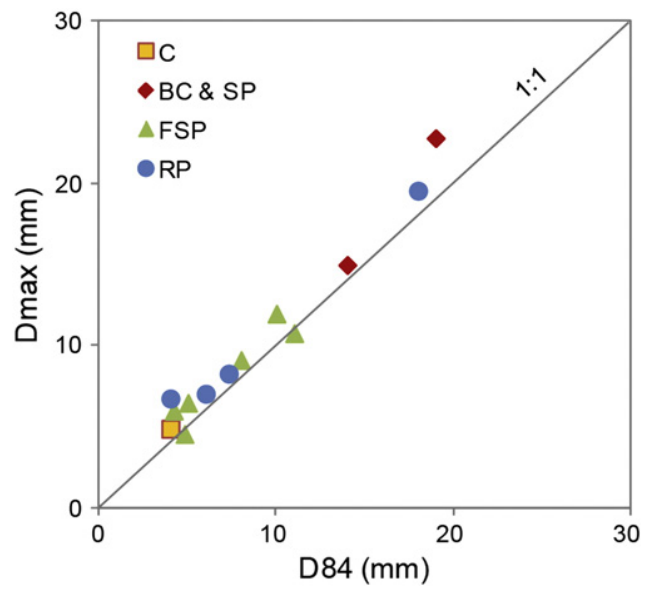

Fig. 5. Empirical relation between surface $D_{\max }$ and surface $D_{84}$ in thirteen selected reaches. See text for explanation of channel types. completed and included an additional headwater weir (C1) as well as 4 removable rectangular pit traps (E2, E3, C2, C3). All sites were monitored hourly to daily during the largest flows in 2006 and 2007 except for the two headwater weirs that had limited access during the snowmelt period (Table 1). At these same sites we assessed channel bed texture using bulk sample analysis (Fig. 6). Bulk samples of surface and subsurface bed material ranging from $20 \mathrm{~kg}$ to $90 \mathrm{~kg}$ (dry weight) were collected at representative locations in the vicinity of each monitoring site (Church et al., 1987; Kondolf et al., 2003). To increase the representativeness of the study period, hence have a more robust basis for assessing hydrologic controls on annual sediment yield (see Section 4.3), monitoring of total yield was extended to 2008.

The efficiency of the removable pit traps $(0.45 \mathrm{~m} \times 0.40 \mathrm{~m} \times 0.15 \mathrm{~m})$, in comparison with other sampling devices (e.g., Helley-Smith sampler) is not known. Sterling and Church (2002) established that $29 \mathrm{~cm}$-wide cylindrical pit traps used in Harris Creek reliably collected fine sand $(0.25 \mathrm{~mm})$ for discharges less than $4 \mathrm{~m}^{3} / \mathrm{s}$. Peak discharges at our pit trap sites ranged from $0.3 \mathrm{~m}^{3} / \mathrm{s}$ to $1 \mathrm{~m}^{3} / \mathrm{s}$ and sediment captured in the traps at the highest flows included all available bed material sizes, from small boulders to sediment finer than $2 \mathrm{~mm}$, which is our grain size cut-off. During the largest discharge events pit traps were emptied frequently to avoid these being filled to capacity, hence compromising the estimate of bedload yield. Given the relatively low peak discharges and sediment yields in the study streams and the ability of the traps to capture the full range of sediment sizes we believe these traps are a reasonably reliable tool of monitoring rates of bedload transport.

Electronic water level recorders at six locations including five of the eight sediment monitoring sites provided a continuous record of water level during the study period (Table 1). At these sites discharge was calibrated with water level annually through salt dilution gauging over the full range of flows (e.g., Day, 1976; Merz and Doppmann, 2006). Salt dilution gauging is a simple, accurate method for estimating discharge in turbulent mountain streams with discharges less than $5 \mathrm{~m}^{2} / \mathrm{s}$. This method is based on the principle that a volume of water moving past a channel section over a period of time can be estimated based on the concentration of a known mass of salt that is diluted in 
Table 1

Monitoring site characteristics.

\begin{tabular}{|c|c|c|c|c|c|c|c|c|c|c|c|c|}
\hline \multirow[t]{2}{*}{ Site } & \multirow{2}{*}{$\begin{array}{l}\text { Drainage area } \\
\left(\mathrm{km}^{2}\right)\end{array}$} & \multirow{2}{*}{$\begin{array}{l}\text { Channel } \\
\text { type }\end{array}$} & \multicolumn{3}{|c|}{ Monitoring frequency $^{a}$} & \multirow{2}{*}{$\begin{array}{l}\text { Trap } \\
\text { type }^{\text {b }}\end{array}$} & \multirow{2}{*}{$\begin{array}{l}\text { Ch. width } \\
\text { monitored } \\
(\%)\end{array}$} & \multirow{2}{*}{$\begin{array}{l}\text { Monitoring } \\
\text { period }\end{array}$} & \multirow{2}{*}{$\begin{array}{l}\mathrm{Q}_{\mathrm{bf}} \\
\left(\mathrm{m}^{3} / \mathrm{s}\right)\end{array}$} & \multirow{2}{*}{$\begin{array}{l}\mathrm{Q}_{\mathrm{p}}^{\mathrm{c}} \\
\left(\mathrm{m}^{3} / \mathrm{s}\right)\end{array}$} & \multirow{2}{*}{$\begin{array}{l}\mathrm{D}_{50}{ }^{\mathrm{d}} \\
(\mathrm{m})\end{array}$} & \multirow{2}{*}{$\begin{array}{l}\mathrm{SSY}^{\mathrm{e}} \\
\left(\mathrm{kg} / \text { day } \mathrm{km}^{2}\right)\end{array}$} \\
\hline & & & SY & Q & X-sec & & & & & & & \\
\hline E1 & 2.2 & Colluvial & A & $\mathrm{C}$ & A & 1 & 100 & 2005-08 & 0.18 & 0.30 & 0.015 & 1.00 \\
\hline E2 & 3.5 & Forced SP & B & $\mathrm{C}$ & B & 2 & 45 & $2006-08$ & 0.28 & 0.29 & 0.05 & 0.90 \\
\hline E3 & 5.0 & B-cascade & B & B & B & 2 & 45 & 2006-08 & 0.30 & 0.63 & 0.061 & 1.65 \\
\hline E4 & 5.7 & Step pool & A, B & $\mathrm{C}$ & B & 3 & 100 & 2005-08 & 0.37 & 0.63 & 0.045 & 1.20 \\
\hline $\mathrm{C} 1$ & 3.0 & Colluvial & A & $\mathrm{C}$ & A & 1 & 100 & $2006-08$ & 0.25 & 0.53 & 0.019 & 0.19 \\
\hline $\mathrm{C} 2$ & 4.0 & Forced SP & B & B & B & 2 & 33 & 2006-08 & 0.56 & 0.86 & 0.02 & 0.52 \\
\hline $\mathrm{C} 3$ & 8.9 & Forced SP & B & B & B & 2 & 28 & $2006-08$ & 0.82 & 1.33 & 0.028 & 0.86 \\
\hline C4 & 10.3 & Riffle pool & A, B & $\mathrm{C}$ & B & 3 & 100 & $2005-08$ & 0.86 & 1.37 & 0.028 & 0.88 \\
\hline C5 & 18.5 & Riffle pool & na & C & B & na & na & $2006-08$ & 0.80 & 1.30 & 0.075 & na \\
\hline
\end{tabular}

a A - once or twice during the freshet, B - hourly during the main peak flow period to daily during intermediate flows and up to weekly during low flows. $\mathrm{C}-\mathrm{continuous}$.

b 1 - Channel spanning weir, 2 - removable pit trap, 3 - channel spanning pit trap.

c Maximum peak flow during monitoring period.

d $\mathrm{D}_{50}$ from Wolman pebble count.

e Specific bed load yield $\left(\mathrm{Kg} / \mathrm{Km}^{2} /\right.$ day) for the 3 years of monitoring (2006-2008).

the flow. Concurrent measurements of discharge and channel crosssectional area were collected along with sediment load at the lower six monitoring sites through three freshets. Discharge was also measured by salt dilution gauging at a supplementary location (C5 in Fig. 1a) downstream from the sediment monitoring sites.

Field-based measurements of discharge and channel cross-sectional area at the monitoring sites allowed: (i) developing an ad hoc area-discharge relation for the study area; and (ii) calculating crosssectional water velocity over the full range of flows, hence yielding an estimation of total stream power $(\Omega)$ and specific stream power $(\omega)$, which we regard being a good reference for those power indices derived elsewhere in the ungauged study reaches from Manning's back-calculated discharges.

Manning's n values were calculated using direct measurements of bankfull discharge, water surface slope at bankfull stage, and bankfull channel cross-sectional area. Calculated Manning's n values were then applied to other reaches with similar morphologies and, together
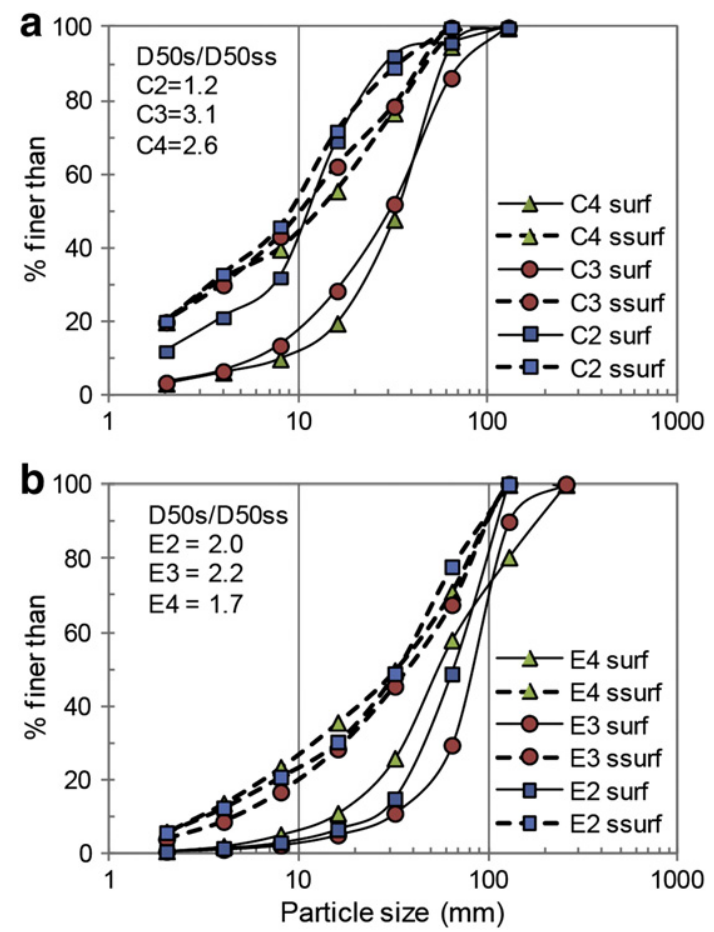

Fig. 6. Surface and subsurface channel texture from bulk sample analysis in (a) Upper Cotton Creek and (b) Elk Creek. Sites C2 to C4 and E2 to E4 are located on Fig. 1a. with measured bankfull width and depth, were used to estimate bankfull discharge $\left(Q_{b}\right)$ at ungauged locations (Fig. 1a). Water surface slope was also used to calculate at-a-station boundary shear stress $\left(\tau_{\mathrm{o}}\right)$.

The area-discharge relation is useful in that it shows how appropriate it is to use drainage area as a proxy for water discharge (e.g., in downstream hydraulic geometry relations). In our case, the scaling exponent denotes a virtually isometric relation (i.e., $\mathrm{Q}=\mathrm{A} 0.07^{1.01}$; $\mathrm{R}^{2}=0.89$ ), ruling out the existence of non-linear trends. The intercept, a measure of the stream base flow, shows a relatively low value compared to humid mountain environments (e.g., Emmett, 1972; Wohl and Wilcox, 2005) and it is comparable to values reported for semi-arid, formerly glaciated watersheds in both Idaho and Colorado (e.g., Whiting et al., 1999; Mueller and Pitlick, 2005).

The combined analysis of discharge and sediment yield at the monitoring stations has been used to: (i) examine the temporal variability of bedload yield in relation to water discharge (Fig. 9); (ii) quantify threshold discharge (Qt) for bed mobility (Fig. 13); and (iii) analyze bedload response across channel morphologies (Fig. 11).

Threshold discharge was identified via stepwise regression (Ryan and Porth, 2007). Specifically, it was defined as the intersection (or breakpoint) of the linear relations describing low levels of bed mobility, also termed Phase 1 transport, and high levels of mobility or Phase 2 transport (Jackson and Beshta, 1982; Ryan et al., 2005; Fig. 13). The breakpoint is selected iteratively so that combined $\mathrm{R}^{2}$ and the relevant $\mathrm{p}$-value between the two regression trends are respectively maximized and minimized (Table 2). At sites $\mathrm{C} 1$ and E1, since these were not monitored frequently, Qt is estimated as largest peak discharge that did not initiate substantial bedload movement (i.e., Gomi and Sidle, 2003).

Finally, to gain further insights on the mechanisms modulating fluvial sediment transport in the study streams, we examine the effects of channel morphology (Section 4.1) on sediment yield (Section 4.2) in three of the intensively monitored sites: C2 (forced step-pool), E4 (step-pool), and C4 (riffle-pool). The combination of sites (i.e., including their upstream 20-m channel stretches) containing distinct sequences

Table 2

Break point analysis results.

\begin{tabular}{lclc}
\hline Site & $\mathrm{Q}_{\mathrm{t}}(\mathrm{l} / \mathrm{s})$ & $\mathrm{R}^{2}$ & $\mathrm{p}$-values \\
\hline E1 & 90 & Estimated & \\
E2 & 152 & $\mathrm{R}^{2}=0.69$ & $\mathrm{p}<0.05$ \\
E3 & 234 & $\mathrm{R}^{2}=0.74$ & $\mathrm{p}<0.05$ \\
E4 & 280 & $\mathrm{R}^{2}=0.87$ & $\mathrm{p}<0.05$ \\
C1 & 250 & Estimated & \\
C2 & 495 & $\mathrm{R}^{2}=0.86$ & $\mathrm{p}<0.05$ \\
C3 & 550 & $\mathrm{R}^{2}=0.59$ & $\mathrm{p}<0.05$ \\
C4 & 504 & $\mathrm{R}^{2}=0.73$ & $\mathrm{p}<0.05$ \\
\hline
\end{tabular}


of channel units, in conjunction with flood variability recorded in the 2006-07 period represents a suitable set up for assessing the sensitivity of channel response to floods. To this purpose, we plot daily sediment yield (in $\mathrm{kg} \mathrm{day}^{-1}$ ) against daily peak discharge $\left(\mathrm{Q}_{\mathrm{d}}\right)$ expressed as a ratio of the threshold discharge $(\mathrm{Qt})$ for initiation of Phase 2 transport (Fig. 11) (Jackson and Beshta, 1982; Warburton, 1990).

\section{Results}

\subsection{Basin structure, channel morphology, and geometry}

Even though the whole physiographic area of the Columbia Mountains has been repeatedly overridden by the Cordilleran Ice Sheet, morphological evidence indicates that glacial erosion was chiefly focused on main valley glaciers (e.g., Moyie Valley; Fig. 1) flowing along the major structural lineaments (Clague, 1989). In particular, the lack of well-defined glacial cirques suggests that ice-flow dynamics on tributary hanging valley glaciers have been relatively stationary. Cotton Creek provides a good example of the foregoing landscape history. Its topography is subdued, with a complex longitudinal profile that exhibits concave-up, straight, and convex portions (Fig. 3a). This pattern translates into a fragmented area-slope transect (Fig. 3b). Morphologically, the profile can be classified into three main components including an upper valley wall (or upland area), a hanging valley, and a valley step that terminates at Moyie Lake. In particular, since the glacially-imposed slopes are gentle to moderate, Cotton Creek lacks topographic boundary conditions that can support mass wasting activity (i.e., debris slides and debris flows) (Jordan, 2002). It follows that inflections in the area-slope relation do not imply process replacement or transition (e.g., Brardinoni and Hassan, 2006).

In view of the above glacial palimpsest, process domains include headmost colluvial reaches (C, Fig. 3a) (sensu Montgomery and Buffington, 1998) that have a distinct disturbance regime from the steep, colluvial analogs typical of steepland areas (e.g., Benda and Dunne, 1997; Jakob et al., 2005). They are characterized by moderate slopes $(0.03-0.41 \mathrm{~m} / \mathrm{m}$; Fig. 7a), so that sediment supply is dominated by soil creep, local bank instabilities, and tree throw, with no evidence of debris-flow activity.
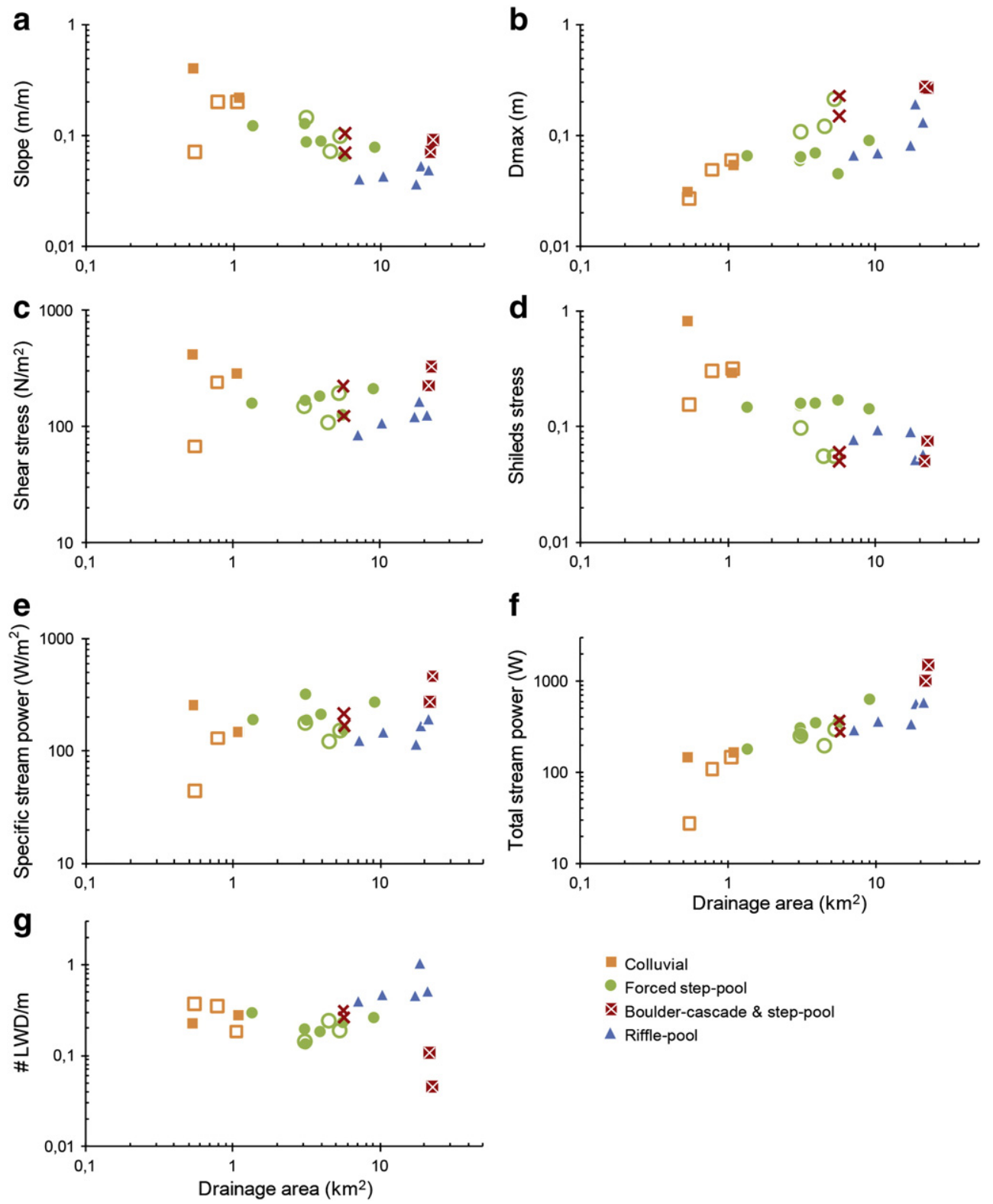

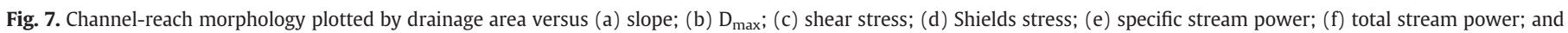
(g) number of LWD pieces per unit channel length. Open and closed symbols represent reaches in Elk and Cotton Creek respectively. 
The spatial distribution of fluvial channel morphologies is controlled by local slope, wood abundance and unlimited availability of glacially-derived sediments (Fig. 1b). Bank undercutting and tree throw (Swanson et al., 1982, 1998) being the dominant mechanisms of sediment supply in fluvial reaches, promote high wood delivery to streams so that plane-bed morphology is highly localized (no discrete reaches) and forced step-pools prevail (9 out of 18 fluvial reaches). Steeper reaches along lower Elk Creek and along the valley step present step-pool and boulder-cascade (SP-BC) morphologies, while rifflepools (RP) are prevalent in the gentler reaches of the hanging valley floor (Figs. 3a and 7a).

Surface $D_{\max }$ exhibits generalized downstream coarsening both along Elk Creek (open symbols) and Cotton Creek (closed symbols; Fig. 7b). This systematic increase in grain size contrasts with reports of D50 from mountain streams of the Washington Cascades (Brummer and Montgomery, 2003) and D84 from New Zealand (Wohl and Wilcox, 2005) which show downstream coarsening on debris flow-dominated reaches and downstream fining along fluviallydominated ones. Heller et al. (2001) attribute the lack of downstream fining in distal reaches of the Hoh River, Washington, to the continuous resupply of coarse glacial material at cutbanks and tributary junctions. The glacial sedimentary imprint in Cotton Creek (Fig. 1b) supports this hypothesis.

Shear stress $(\tau)$ and specific stream power $(\omega)$ across the study reaches do not show any systematic variation with drainage area (hence with discharge). The former variate plots consistently between 85 and $330 \mathrm{~N} / \mathrm{m}^{2}$ (Fig. 7c), the latter spans between 120 and $320 \mathrm{~W} / \mathrm{m}^{2}$ (Fig. 7e). In contrast, total stream power displays a well-defined downstream increase across channel types (Fig. 7f). This finding contrasts with previous reports (Wohl and Wilcox, 2005) that have shown progressive downstream increase of total power along debris-flow dominated reaches and monotonic decline along fluvially-dominated counterparts. Given that both total power and $\mathrm{D}_{\max }$ increase with contributing area, it follows that $\mathrm{D}_{\max }$ increases as a function of total stream power $\left(D_{\max }=2^{*} 10^{-3} \Omega^{0.61} ; R^{2}=0.55\right)$. A similar relation between D50 and total stream power has been reported for larger drainage basins $\left(20-380 \mathrm{~km}^{2}\right)$ of central and northern Idaho (Whiting et al., 1999). Shields stress (Fig. 7d), even though characterized by high scatter, due to the downstream increase in $\mathrm{D}_{\max }$, declines progressively downstream. In particular, the area-Shields stress relation yields a good discrimination between colluvial and alluvial reaches.

The number of LWD pieces per unit channel length (LWD density) shows a complex pattern (Fig. $7 \mathrm{~g}$ ). Values plot between 0.14 and 0.37 along the confined colluvial and fluvial reaches (valley width range: $5 \mathrm{~m}-15 \mathrm{~m}$ ) located upstream of the Elk-Upper Cotton confluence. Downstream, in riffle-pool-bar morphologies of the unconfined hanging valley floor (valley width range: $30 \mathrm{~m}-100 \mathrm{~m}$ ) greater total stream power and valley-side storage opportunity impart a further increase of LWD density, which peaks to 1.06. Finally, when Cotton Creek enters the relatively steep and entrenched step-pool/boulder-cascade reaches of the valley step, drastically reduced wood storage conditions and a further increase in transport capacity (i.e., total stream power) impart an abrupt decline in LWD density (0.04-0.11).

Downstream hydraulic geometry relations (DHG, Fig. 8) in Cotton Creek are statistically robust (note high $\mathrm{R}^{2}$ values) and show scaling exponents that are in good agreement with the relation originally shown by Leopold and Maddock (1953). This finding suggests that lowland DHG relations can apply to mountain streams, with abundant LWD structures and glacially-imposed slopes, as long as mass wasting disturbance is not active.

Inter-basin variability between Elk Creek and Upper Cotton Creek is minimal in terms of channel slope, total stream power, and LWD density (Figs. 3a and 7). However, differences are evident with respect to $D_{\max }$ and correlated variables, such as Shields stress $\left(\tau / D_{\max }\right)$ and relative roughness $\left(D_{\max } /\right.$ bankfull depth). In particular, along fluvial reaches Elk Creek displays consistently higher surface $D_{\max }$ and relative

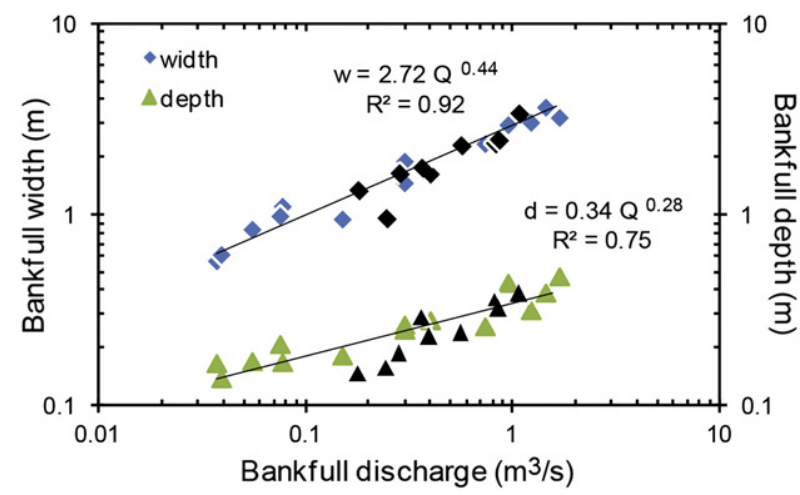

Fig. 8. Downstream hydraulic geometry across the study reaches. Black symbols indicate reaches with field-measured discharges.

roughness than Upper Cotton Creek, while Shields stress plots systematically lower.

\subsection{Daily bedload yield}

Bedload mobilization typically occurs with increasing stream flow early in the spring snowmelt period and continues episodically throughout the spring peak flow period, terminating during the final recession flows in mid-summer (Fig. 9). Flow duration analysis indicates that discharges capable of mobilizing bedload occurred between $0 \%$ and $25 \%$ of the time, depending on the station, between the beginning of March and the end of June. We did not observe any bedload movement during the seasonal low-flow period between the months of July and March.

Examination of the data at the stations with higher temporal resolution (i.e., E4 and C4) in 2006 and 2007 shows (i) an intuitive direct dependence of daily yield on water discharge $(\mathrm{Q})$; and (ii) high variability of Q temporal pattern in the two seasons monitored (Fig. 9). Both the 2006 and 2007 freshets included multiple sediment mobilizing peak flows. In particular, the structure of the 2007 hydrograph is regarded as typical of a spring freshet in the southern Columbia Mountains (i.e., Whitaker et al., 2003; Jordan, 2006). Maximum Q in 2006 was the largest recorded in the four study years and is estimated to be a 10 -year flood based on the closest $(50 \mathrm{~km})$ long-term gauging site that displays similar physiographic characteristics and meteorology (Environment Canada Station 08NH016). Bankfull level was also reached in 2007 at 7 of the 9 monitoring sites, in this case maximum $\mathrm{Q}$ was estimated as a 2-year flood.

Higher daily yields tend to mimic the temporal pattern of $Q$ peaks. However, daily yield response is complex: largest yields are not necessarily associated with the seasonal maximum discharge and vice versa $Q$ peaks do not necessarily generate sediment mobilization. For example, in both study streams the second freshet peak of 2006 produces the greatest daily yield even though this event was not the largest of the hydrological season (Fig. 9).

Analysis of bedload yield associated with rising and falling limbs of individual $Q$ peaks documents that rising limbs (including the peak) mobilize far more sediment than the corresponding falling limbs (Fig. 10). Differences are especially large for Elk Creek, in which the median mobilized mass during the rising component of a flood event is about one order of magnitude greater than the falling one (i.e., $100 \mathrm{~kg}$ vs. $10 \mathrm{~kg}$ ). In terms of inter-basin comparison, while the size variability of sediment pulses in the two study streams largely overlap during the falling limb, in Elk Creek rising limb-driven sediment transport is about three times higher than in Upper Cotton Creek (Fig. 10).

The mechanism responsible for higher bedload transport during the rising stages of the hydrograph becomes clear when considering the Shields stresses associated with mobilization of bed material. At both 

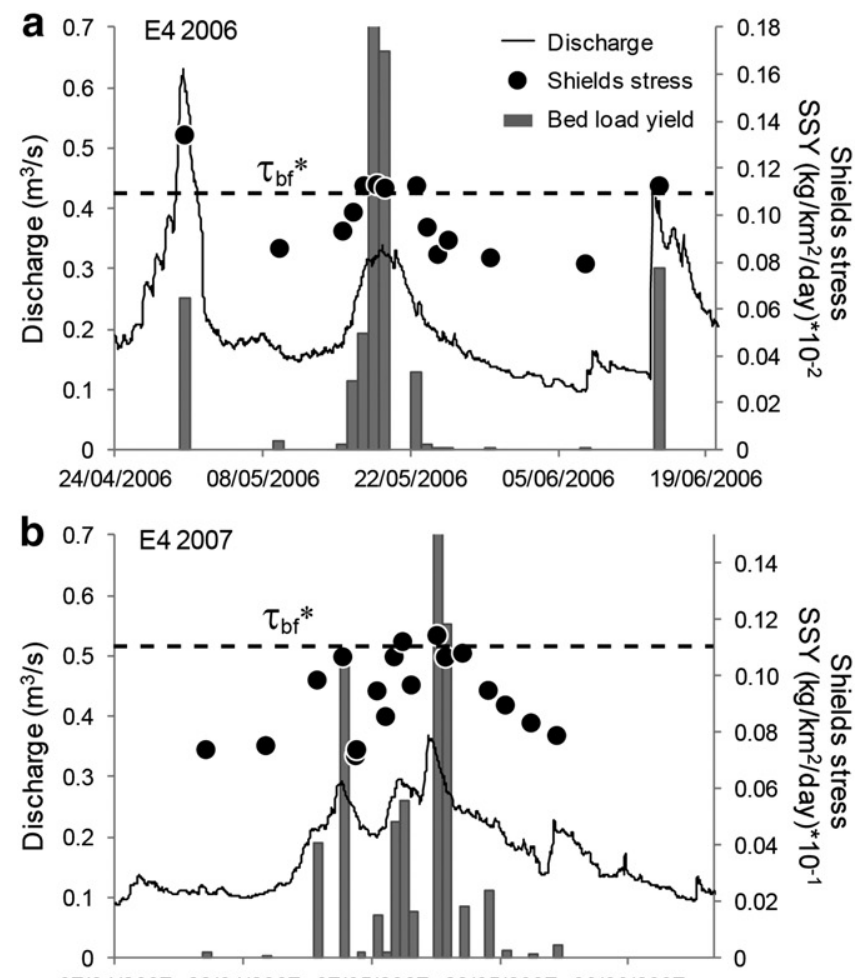

07/04/2007 22/04/2007 07/05/2007 22/05/2007 06/06/2007
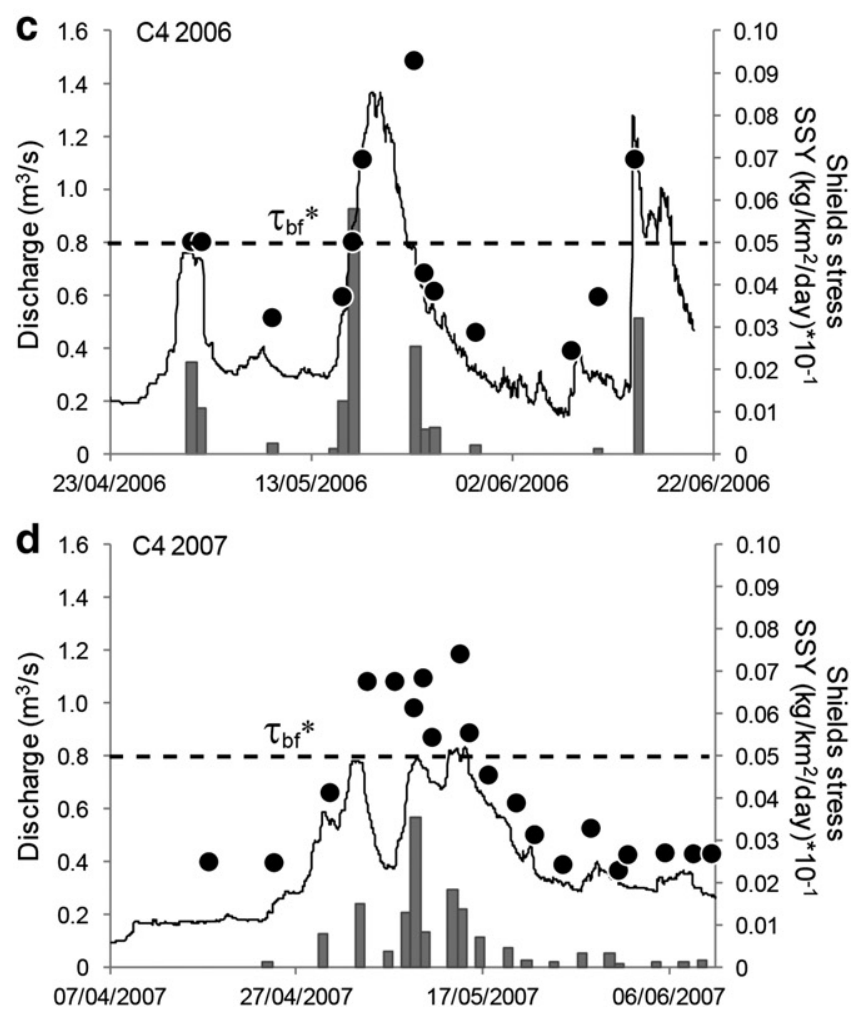

Fig. 9. Water discharge hydrograph with daily specific yield and associated Shields stress at monitoring sites C4 and E4. Dashed lines indicate Shields stress at bankfull. Note scaling factors for specific bed load yield in the secondary y-axes.

E4 and C4 we observe sudden increases of bedload once Shields stress (based on the surface $D_{50}$ ) approaches bankfull $\left(\tau^{*}{ }_{b f}\right)$. As discharge starts to recede there is a corresponding drop in bedload yield even when Shields stress remains above bankfull (Fig. 9). The fact that $\tau^{*}{ }_{b f}$ values in C4 and E4 (i.e., respectively 0.05 and 0.11, Fig. 9) lie within

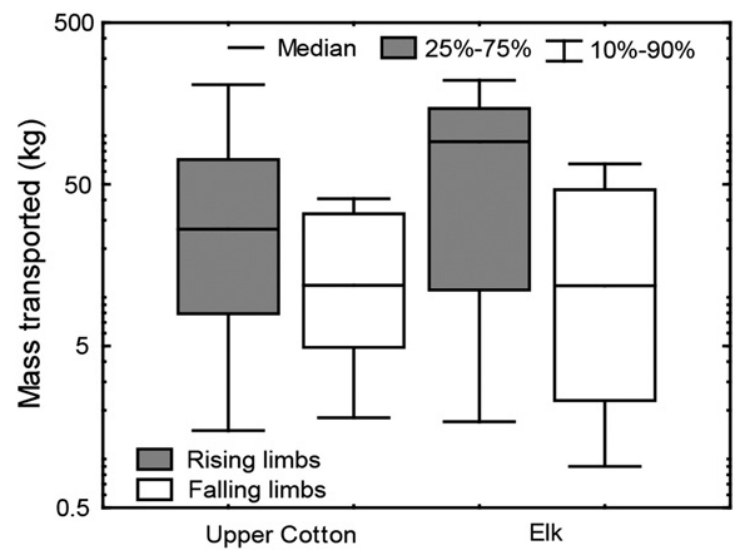

Fig. 10. Box-plot showing the size distribution of transported mass during the rising and falling limb in Upper Cotton Creek and Elk Creek.

the range associated with the destabilization of the armor layer in similar snowmelt-dominated streams of North America (i.e., Mueller et al., 2005; $\left.\tau^{*}{ }_{\text {bf }}(0.05-0.128), \mathrm{H} / \mathrm{D} 50<5\right)$, suggests that armoring must play a prominent role in terms of sediment supply. The dynamics associated with the supply and subsequent exhaustion of bedload material are examined in greater detail in the next section.

\subsection{Variability of bedload yield across channel morphologies}

In the presentation of bedload sediment dynamics in forced step-pools (C2), free-formed step-pools (E4), and riffle-pools (C4), we proceed from 2007, the average flood year, then continue with the assessment of the more severe hydrological conditions of 2006 (i.e., 10 -year flood). In 2007 we observe distinct yield-discharge relations in the three channel types. In riffle pools (C4) rising and falling stages plot approximately along the same discharge-yield relation (Fig. 11f) indicating adequate sediment supply (no exhaustion) throughout average floods. Free-formed step pools (E4) seem to behave somewhat differently, in that we note modest clockwise hysteresis (i.e., sediment yield in the rising stage is higher than that associated with the falling stage) for QdQt $^{-1}<1.5$ (Fig. 11d). In snowmelt gravel-bed streams clockwise hysteresis in bedload yield at the seasonal scale has been attributed to depletion of the available sediment mobilized during the rising limb of the hydrograph (Nanson, 1974; Moog and Whiting, 1998).

Lastly, at the forced-alluvial site (C2) we observe delayed mobilization of sediment during the rising stage that results in a counter-clockwise hysteresis (Fig. 11b). These bedload dynamics reveal substantial channel-bed stability conditions so that very little sediment can move until break-up of the surface armor layer occurs at flows approaching bankfull. In particular, higher transport rates across the falling limb period are associated with the mobilization of fine gravels, previously sheltered by armoring, which remain mobile after the bed surface has re-stabilized (Reid et al., 1985; Lisle, 1986).

In 2006, while the behavior of the riffle-pool channel (C4) (Fig. 11e) mimics substantially that observed in 2007 , the other two sites exhibit a clockwise hysteresis pattern. Namely, the hysteresis loop in the forced-alluvial site (C2) (Fig. 11a) has a larger amplitude compared to the purely alluvial one (E4) (Fig. 11c), indicating more pronounced conditions of sediment exhaustion during the falling stage.

Comparisons of average rising limb and falling limb grain-size distributions in C2, C4, and E4 provide further insights while corroborating foregoing interpretations on the mechanisms controlling bedload yield variability (Fig. 12). In the riffle-pool site (C4) the grain-size distributions associated with the rising and falling limbs are nearly identical in both years (Fig. 12c). These patterns, which agree with prior outcomes showing that rising and falling stages lie approximately 

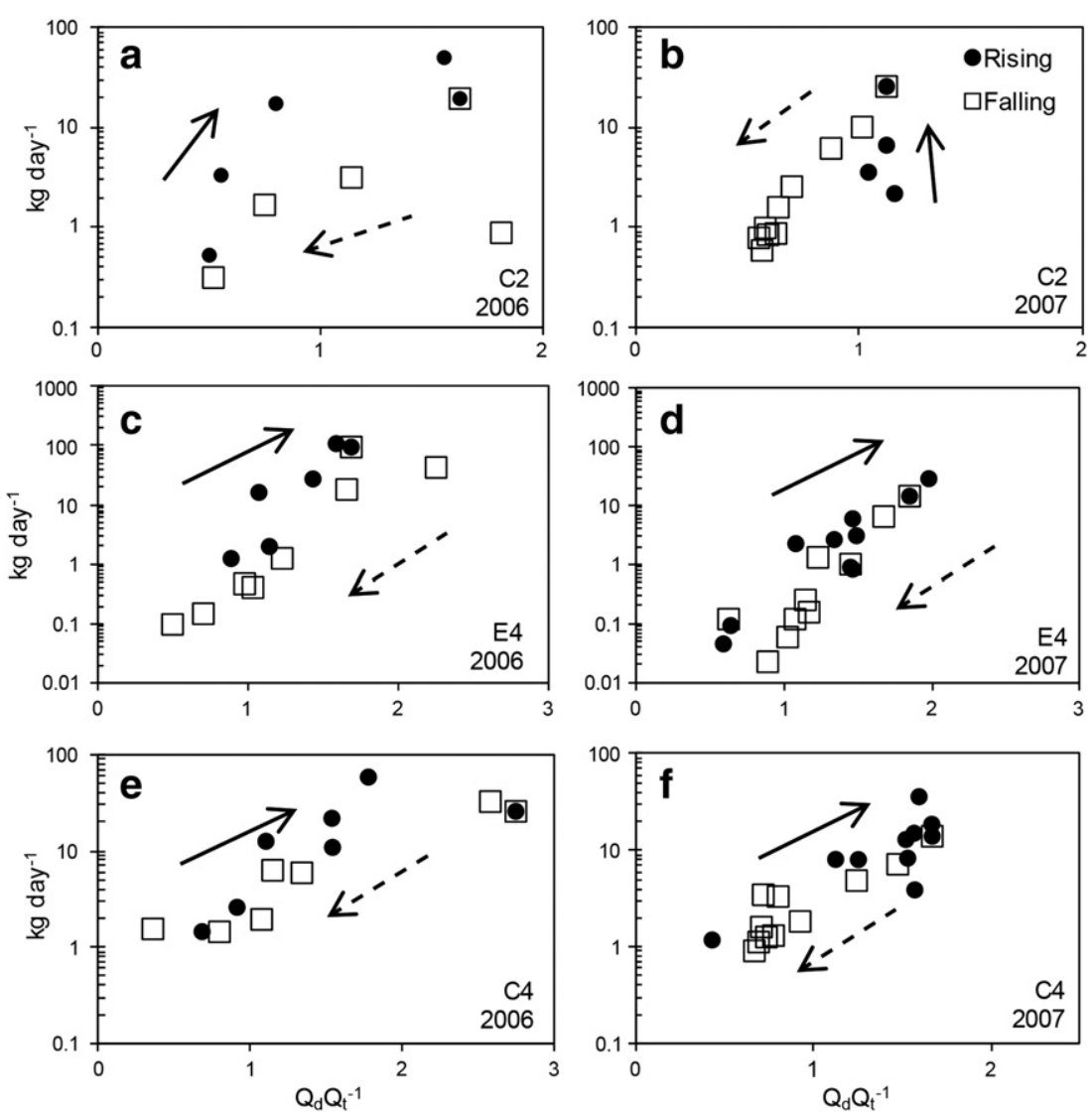

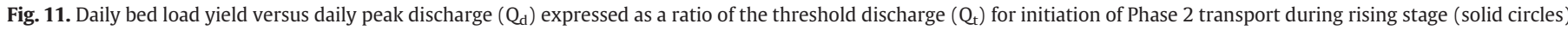
and falling stage (open squares) periods. (a) C2 in 2006; (b) C2 in 2007; (c) E4 in 2006; (d) E4 in 2007; (e) C4 in 2006 ; and (f) C4 in 2007.

on the same discharge-yield relation (Fig. 12c), point to sediment dynamics typical of transport-limited conditions. By contrast, in the coarse-grained step-pool site (E4) rising stages mobilize consistently coarser bed-load fractions than the falling stages (Fig. 12b). This outcome is attributed to the effect of exhaustion of sediment supply in conjunction with the reduced mobility of the coarsest fraction as the armor layer re-forms for QdQt ${ }^{-1}<1.5$.

Sediment dynamics at the forced-alluvial site (C2) in 2006 and 2007 appear to be the most diverse. We attribute this behavior to the presence of LWD. In 2007, loads transported during falling limbs are finer than the rising counterparts, a pattern consistent with increased mobilization of fines following the armor layer break-up. In 2006, where we had observed the largest difference between rising and falling limb yields (Fig. 12a), coarser textured falling limb loads indicate a depletion of fines following the large magnitude flood event (open squares, Fig. 12a). According to morphological changes observed in the field, the 10-year flood event was capable of mobilizing material stored behind LWD; material that was not accessible to stream flow in 2007.

\subsection{Annual sediment yield}

In order to decipher postglacial sedimentary responses in headwater alluvial systems and assess relevant hydrological controls, we examine sediment yield at much coarser temporal (annual) and spatial (regional) scales. In the two study basins specific sediment yield (SSY; expressed in $\mathrm{kg} \mathrm{km}^{-2} \mathrm{day}^{-1}$ ) tends to increase with drainage area (Table 1). During the study period, Elk Creek displays consistently higher SSY than Upper Cotton Creek. Previous monitoring in headwater tributaries of Gold Creek, a basin that shares its western divides with Upper Cotton Creek, indicate that bedload and suspended load exhibit a 1:6 ratio (Jordan, 2006). By applying this ratio to the bedload yields of our study sites we obtain a first-order estimate of suspended yield (Fig. 14; given the intrinsic spatial variability associated with suspended sediment yield, we report 50\% error bars). These estimates, which plot along the area-yield scaling relation defined by larger basins (50-30,000 $\mathrm{km}^{2}$ ) of the Columbia physiographic region (Church et al., 1999), indicate a sedimentary pattern of downstream degradation, ultimately the result of contemporary fluvial reworking of inherited glacial and glaciofluvial deposits (Church and Slaymaker, 1989).

Within the context of formerly glaciated landscapes, an evaluation of the hydrological effects on downstream patterns of sediment yield has not been previously addressed. In the next section we explore to what extent hydrologic forcing can control annual bedload yield $\left(\right.$ ASY; $\mathrm{kg} / \mathrm{km}^{2}$ ). To this purpose, we conduct a multiple step-wise regression. Hydrological variables include: (1) magnitude of the maximum annual peak flow measured as the ratio of annual peak discharge to threshold discharge for bed mobility ( $\mathrm{QpQt}^{-1}$ ) (Table 2; Fig. 13); (2) duration of flows over threshold discharge (Dr); (3) number of peaks over threshold discharge (nPk); and (4) percent exceedence of flows above threshold discharge (Ex).

Simple correlation analysis (Table 3 ) shows that annual sediment yield is chiefly correlated with the number of peaks over threshold. We also note that virtual complete correlation exists between 'Duration' and '\% exceedence', and that these two variables correlate well with $\mathrm{QpQt}^{-1}$. 'Duration' was excluded from stepwise regression analysis due to non-normally distributed residuals, even after a number of transformation attempts. The results of the stepwise regression indicate that $\mathrm{nPk}$ alone is the strongest predictor of ASY (Model 1, Table 4). Model strength does not improve after including QpQt ${ }^{-1}$ (Model 2), unless one removes the two colluvial sites (E1 and $\mathrm{C} 1$ ) from the regression (Model 3).

To our knowledge only one other study (Ouimet and Dethier, 2002) has recognized the influence of $\mathrm{nPk}$ in explaining annual variability in 

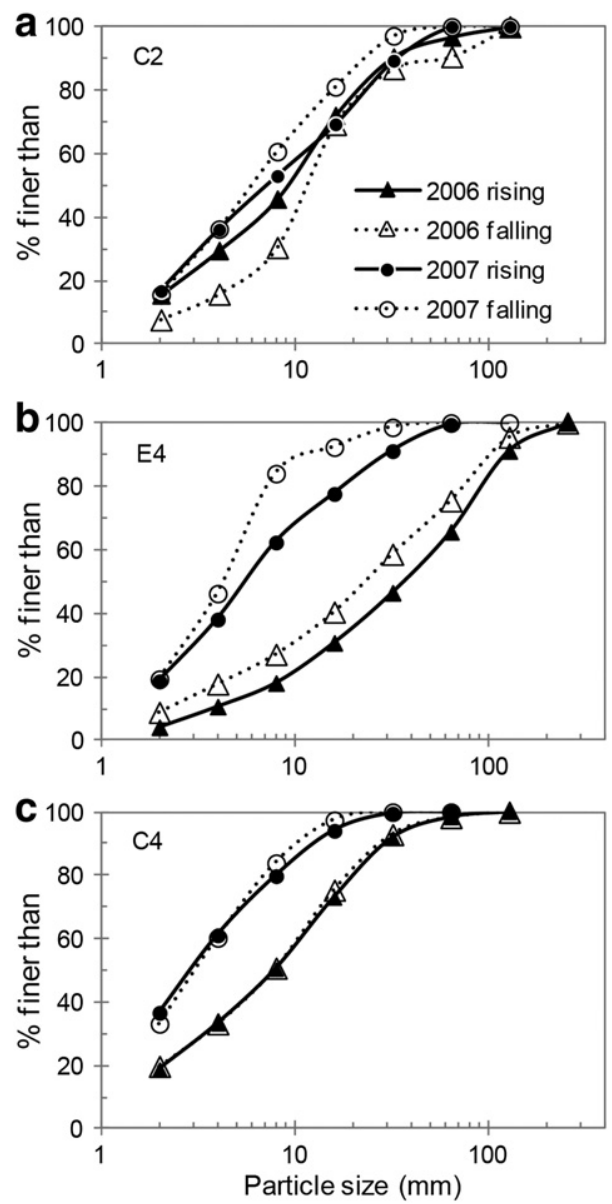

Fig. 12. Grain-size distribution of bed loads associated with rising and falling stages at sites: (a) C2; (b) E4; and (c) C4.

sediment yield. The study investigated controls on sediment flux in Birch Brook Creek, a headwater basin in northwestern Massachusetts, whose annual hydrograph is characterized by numerous rain-on-
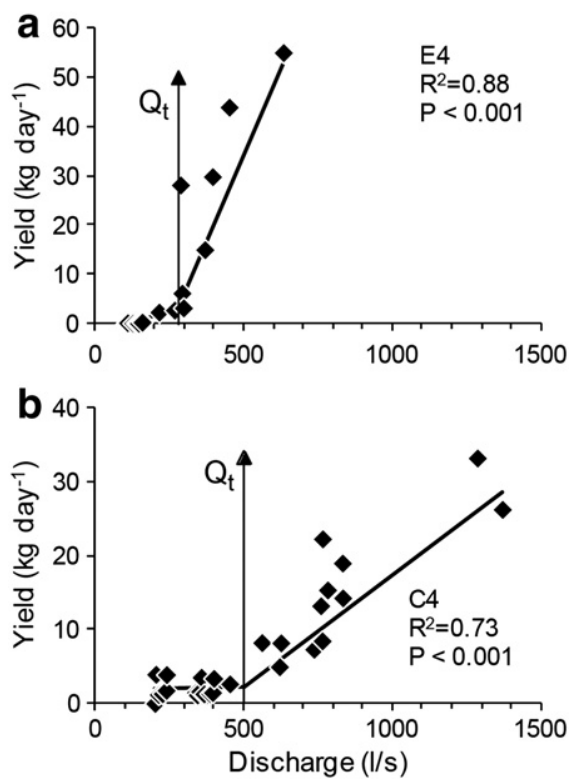

Fig. 13. Breakpoint analysis for sites E4 and C4. Breakpoints define the threshold discharge at the intersection of the linear relations describing low levels of bed mobility (Phase 1 transport) and high levels of mobility (Phase 2 transport). Stepwise regression is used to identify the threshold discharge that maximizes the cumulative $\mathrm{R}^{2}$ and minimizes the overall p-value of the two regression lines (Ryan and Porth, 2007).
Table 3

Correlation matrix.

\begin{tabular}{llllll}
\hline & $\%$ Ex & Dr & nPk & Qp/Qt & ASY \\
\hline \% Ex & 1 & & & & \\
Dr & 0.9918 & 1 & & & \\
nPk & 0.5977 & 0.6406 & 1 & & \\
Qp /Qt & 0.7485 & 0.7476 & 0.4592 & 1 & \\
ASY & 0.4329 & 0.4597 & 0.8019 & 0.3904 & 1 \\
\hline
\end{tabular}

snow and rain-only peak events that occur throughout the year. Using simple linear regression, the authors test the strength of bivariate relations between annual bedload yield and meteorological and discharge variables (i.e., annual precipitation, duration of flows, and number of peaks over bankfull flow). Study results indicated that number of peaks over bankfull discharge and duration of flows in excess of bankfull discharge respectively explained $70 \%$ and $82 \%$ of the variability of annual bedload yield however, duration of discharge was estimated as a function of peak discharge magnitude rather than measured directly. The variable 'number of days in excess of Qbf', a more direct estimate of duration of flows above threshold discharge, explained only $35 \%$ of the variability in annual yield.

\section{Discussion}

This study characterizes the linkages between landscape structure, channel-reach morphology, and bedload sediment dynamics in headwater streams of the Columbia Mountains, Canada. In so doing, it complements prior studies conducted in formerly glaciated larger fluvial systems of Idaho (e.g., Whiting et al., 1999). The combination of bedrock geology, tectonic activity, but chiefly Pleistocene glaciations imposes local slope and valley width, which in turn modulates stream channel morphodynamics. Morphological and sedimentological evidence indicates that during the Last Glacial Maximum erosion associated with advancing glaciers primarily occurred along the major valleys, while intervening upland areas experienced a gradual build-up of ice as valley glaciers coalesced (Ryder, 1981). As a result, this region of the Canadian Cordillera is characterized by a subdued, plateau-like topography, in places interrupted by major, entrenched valleys (i.e., relict glacial troughs).

Even though the glacial palimpsest generates stepped longitudinal profiles (e.g., Cotton Creek), inflections in the area-slope space do not impart geomorphic process transitions (Fig. 3 ) and the landscape is fluvially dominated, with mass-wasting activity relegated to the vicinity of a few highest peaks. In contrast with the steep, rugged terrain of coastal British Columbia (Brardinoni and Hassan, 2006, 2007), colluvial channels are confined to the headmost tips of the drainage network and do not support debris-flow activity, so that the significance of this geomorphic process at the local and regional scales is negligible.

The number of LWD pieces per unit channel length increases downstream with increasing stream power as long as the channel is unconfined and provides room for wood storage on adjacent riparian areas (i.e., hanging valley floor of Cotton Creek). Where step-pool and boulder-cascade morphologies are entrenched in high-power reaches (i.e., valley step), wood is either transported downstream or remains

Table 4

Stepwise multiple regression analysis results.

\begin{tabular}{llllll}
\hline Model & Regression equation & $\mathrm{n}$ & $\mathrm{R}^{2}(\operatorname{adj})$ & $\mathrm{F}$ value & P value $(\operatorname{adj})$ \\
\hline 1 & $\mathrm{ASY}=-5.6+\left(14.6^{*} \mathrm{nPk}\right)$ & 27 & 0.63 & $\mathrm{~F}=45.02$ & $\mathrm{p}<0.001$ \\
2 & $\mathrm{ASY}=-7.4+\left(1.4^{*} \mathrm{Qp} / \mathrm{Qt}\right)+$ & 27 & 0.61 & $\mathrm{~F}=21.67$ & $\mathrm{P}<0.001$ \\
& $\left(14.4^{*} \mathrm{nPk}\right)$ & & & & \\
3 & $\mathrm{ASY}=-16.2+\left(9.4^{*} \mathrm{Qp} / \mathrm{Qt}\right)+$ & 20 & 0.65 & $\mathrm{~F}=18.53$ & $\mathrm{p}<0.001$ \\
& $\left(14.2^{*} \mathrm{nPk}\right)$ & & & & \\
\hline
\end{tabular}


inactive (overhanging), so that the number of LWD pieces per unit channel length drops dramatically (Fig. $7 \mathrm{~g}$ ).

The spatial distribution of channel-reach morphology is controlled by local slope, in conjunction with wood abundance. Local slope, imposed by relict glacial landforms, produces the classic bouldercascade/step-pool/plane bed/riffle-pool sequence (Montgomery and Buffington, 1997), which is reset by the presence of hanging valleys (Brardinoni and Hassan, 2007). This sequence is further altered by the abundance of active LWD pieces, in turn modulated by channel confinement and total stream power. LWD abundance dictates: (i) which channel types are dominant (i.e., forced step-pools) and which are excluded (i.e., plane bed reaches; Fig. 7a); and (ii) the spatial distribution of forced morphologies so that for the reasons detailed above, forced step-pools do not appear downstream of the hanging valley.

Previous studies conducted in steep mountain streams have shown that the area-slope inflection marking the transition between colluvial (debris-flow) channels and downstream fluvial analogs imparts inflections in downstream trends of stream power indices and sediment caliber (Brummer and Montgomery, 2003; Wohl and Wilcox, 2005). In our study creeks, the composite area-slope trend does not affect the downstream variation of total stream power and $D_{\max }$, and both variables exhibit monotonic increasing trends with drainage area. According to the foregoing comparison, area-slope inflections would be effective in modulating stream power and maximum sediment caliber only when the threshold of debris-flow initiation/transport (i.e., slope.>40\%) is crossed, a threshold supported by extensive field-based data (Fannin and Rollerson, 1993; Jordan, 2002). Given that both total power and $D_{\max }$ increase with contributing area, it follows that $D_{\max }$ increases as a function of total stream power $\left(D_{\max }=2^{*} 10^{-3} \Omega^{0.61} ; R^{2}=0.55\right)$.

DHG relations in the study area are well developed and are insensitive to area-slope inflections (cf. Figs. 3b and 8). In particular, discharge-width and -depth scaling relations in Cotton Creek are statistically stronger $\left(0.75<\mathrm{R}^{2}<0.92\right)$ than those reported for basins of comparable size, characterized by debris-flow dominated headwaters (Brummer and Montgomery, 2003; Wohl and Wilcox, 2005; Brardinoni and Hassan, 2007). Interestingly, average $\Omega / D_{\max }$ (i.e., $3,600 \mathrm{~kg} / \mathrm{s}^{3}$ ) plots well below the $10,000 \mathrm{~kg} / \mathrm{s}^{3}$ threshold condition proposed by Wohl (2004) for attaining well developed DHG relations in mountain channels. This outcome indicates that such energy-based limit to DHG does not hold for Cotton Creek and possibly for similar fluvially-dominated headwater channels of this physiographic region.

DHG scaling exponents roughly conform to those originally reported by Leopold and Maddock (1953), as well as to more recent ones obtained for larger fluvial systems located within the Columbia River basin, Idaho (Whiting et al., 1999). In this regard, the present work extends the validity of fluvial DHG relations to smaller and steeper fluvial systems, characterized by more complex topography and coarser beds.

In Cotton Creek while the spatial distribution of free-formed reach morphologies is chiefly controlled by local slope, downstream patterns of the coarse grain-size fraction, bankfull width, bankfull depth, and stream power are all insensitive to systematic changes of glacially imposed slope. This is an indication that these variables are adjusted to the contemporary snowmelt-driven water and sediment transport regimes, and as such are able to compensate for the glacially-imposed boundary conditions.

The spring (March-June) snowmelt hydrograph of the Columbia Mountains typically displays a number of distinct peaks that are triggered by periods of warm weather and, to a minor extent, by rainon-snow events (McCabe et al., 2007). In the study sites, discharge peak events on average are capable of triggering bedload transport for about $12 \%$ ( 11 days) of the spring snowmelt period, with average specific yields ranging between 0.2 and $2 \mathrm{~kg} / \mathrm{km}^{2}$ per day.

Examination of sediment transport at finer resolution (shorter temporal scales) shows that peak flows of a given magnitude are not necessarily associated with bedload transport and higher yields are observed on rising limb of peak flows compared to those associated with falling limb counterparts. Differences in bedload mobility between rising and falling flood discharges have been reported elsewhere (Wohl, 2010). In steep mountain channels subject to landslide sediment inputs and debris-flow activity, the decrease in bedload yield following large floods is typically interpreted as the result of in-channel sediment depletion/exhaustion (supply-limited conditions) (e.g., Nanson, 1974; Alvera and Garcia-Ruiz, 2000; Gomi and Sidle, 2003). In forested streams where sediment is supplied from channel banks or upstream reaches, lower yields associated with falling hydrographs have been related to the break-up and subsequent re-establishment of a channel-bed armor layer (e.g., Sidle, 1988; Kuhnle, 1992). Finally, in low-gradient alluvial systems, depletion or seasonal exhaustion of sediment availability has also been invoked as the cause of decreased bed mobility following peak flows (Dietrich et al., 1989; Moog and Whiting, 1998).

Comparison of relevant Shields stress values with published data from snowmelt-dominated streams in western North America (Mueller et al., 2005), provides quantitative confirmation that in alluvial reaches of Elk and Upper Cotton Creek (E4 and C4) the discrepancy between sediment yields during rising and falling stages of the hydrograph is modulated by the break-up and subsequent re-development of the surface armor layer (Fig. 9).

A closer look at sediment dynamics in three representative sites characterized respectively by forced step-pools, and free-formed steppools and riffle-pools allows detailing causal linkages between local morphology and channel response (i.e., bedload transport) to imposed discharges. Examination of daily bedload yield expressed as a function $\mathrm{Q}_{\mathrm{d}} \mathrm{Q}_{\mathrm{t}}^{-1}$ (daily peak discharge normalized by threshold discharge) is instructive (Fig. 11). The disparity in hydrological forcing during the two years of monitoring:

(i) had virtually no effect in the riffle-pool site (C4), with rising and falling bedload yields displaying comparable magnitudes. This pattern is characteristic of transport-limited systems.

(ii) imparted in free-formed step-pools (E4) a clockwise hysteresis loop (indicative of sediment exhaustion dynamics), whose amplitude was proportional to the recurrence interval of the peak flood.

(iii) induced in forced step-pools (C2) a hysteresis reversal, from a distinct counter-clockwise pattern in 2007 to a wide clockwise loop in 2006. In the latter case, the 10-year flood event has made available material stored behind and above LWD, which is typically inaccessible in average flood years (supplylimited conditions).

The foregoing channel responses agree with the conceptual framework that considers channel-reach morphology in mountain streams a qualitative expression of the competition between water/sediment supply and transport capacity (Montgomery and Buffington, 1997, 1998). In this perspective, riffle-pools are transport-limited systems whereas step-pools and forced step-pools are increasingly limited by sediment supply.

Annual bedload specific yield in Elk and Upper Cotton Creek increases as a positive power function of drainage area. Similar trends, which have been reported for suspended yield across larger fluvial systems $\left(\sim 10^{2}-10^{4} \mathrm{~km}^{2}\right)$ of British Columbia (e.g., Church and Slaymaker, 1989; Church et al., 1999), are diagnostic of ongoing degradation. This sedimentary pattern has been explained as the result of contemporary fluvial reworking (i.e., mainly bank erosion) of paraglacial sediment surplus (i.e., valley fills) emplaced about 10,000 years ago, during the last continental deglaciation. This interpretation is supported by the spatial distribution of glacial (ablation till), sandy gravelly glaciofluvial (kame terraces) and sandy gravelly fluvial deposits though which the study streams are actively eroding (Fig. 1b). 
Based on bed- and suspended-load monitoring efforts conducted in headwater streams adjacent to our study basins (Jordan, 2006), we obtain a first-order approximation of the annual suspended load in Elk and Upper Cotton Creek. Derived total yields plot along the same scaling relation described by larger basins of the Columbia Mountains region (Fig. 14; Church et al., 1999). Since tree throw and bank erosion are the main mechanisms of sediment supply from till-mantled terrain to Elk and Upper Cotton Creeks, these outcomes provide further empirical support to that original explanation (i.e., Church and Slaymaker, 1989) and extend it to fluvial systems as small as $2 \mathrm{~km}^{2}$.

Stepwise regression analysis, conducted to examine the temporal variability of annual sediment yield in relation to water discharge, suggests that bedload yield is chiefly related to the number of peaks over threshold (nPk, Table 4) rather than the magnitude of peak discharge $\left(\mathrm{QpQt}^{-1}\right)$.

The number of peaks over threshold in Elk $(\mathrm{nPk}=42)$ and Upper Cotton Creek $(\mathrm{nPk}=23)$ also explains the higher bedload yield recorded in the former system (Table 1) across the 2006-08 study period. In this regard, a crucial question needs to be addressed: what controls the inter-basin variability of $\mathrm{nPk}$ ?

Recent studies investigating snowmelt dynamics in mountain environments indicate that, at the basin scale, differences in topographic conditions can combine to generate different snowmelt responses (Ellis et al., 2010; Pomeroy et al., 2011). Therefore, a first-order explanation of nPk variability can be pursued via analysis of basic topographic variables such as elevation (i.e., hypsometric curve), slope, and aspect (Fig. 2).

In regard to elevation, previous works have shown that: (i) peak flows in mountain basins are chiefly controlled by snowmelt occurring at the $\mathrm{H} 20-\mathrm{H} 60$ elevation band (that is, $20-60 \%$ basin upper portion); and (ii) snowmelt from the headmost areas of a watershed does not contribute substantially to hydrograph peaks, due to poor surface flow connectivity to the main channel network (Gluns, 2001; Whitaker et al., 2002). Given that Elk and Upper Cotton Creek have virtually identical hypsometry in the H20-H60 elevation band (Fig. 2a) we conclude that elevation likely does not affect nPk inter-basin variability. The same conclusion applies to slope gradient, as Elk and Upper Cotton share similar slope distributions (Fig. 2b).

As will become clear, slope aspect is the topographic factor that better explains the complex hydrologic response observed in the two study tributaries. Natural shading on north-facing slopes, prevalent in Upper Cotton Creek (Fig. 2c), would result in relatively slow snowmelt driven by longwave radiation (Jost et al., 2007; Ellis et al., 2010), hence dampening the effects of any external meteorological perturbation on snowmelt rates. In contrast, terrain with prevalent south-facing components (i.e., Elk Creek) by experiencing faster snowmelt, dominated by direct

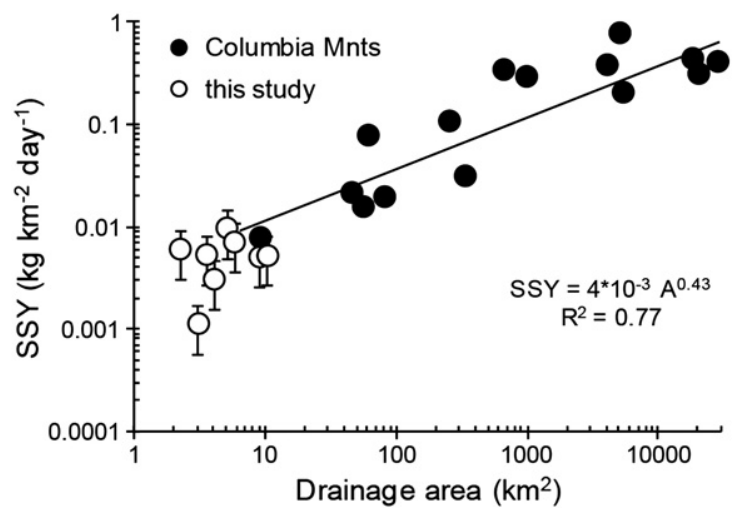

Fig. 14. Suspended sediment yield as a function of drainage area for the Columbia Mountains physiographic region. Filled symbols are yields published by Church et al. (1999); open symbols are yields estimated at the eight monitoring sites in Cotton Creek. Bars indicate 50\% error around estimated values (Jordan, 2006). shortwave radiation, would be more sensitive to meteorological fluctuations, generating peaks over bedload threshold more frequently.

The importance of hydrograph variability on sediment yield agrees with previous reports showing poor correlation between peakflow magnitude and annual yield (e.g., Warburton, 1990; Troendle and Olsen, 1994; Ryan and Dixon, 2008). Temporal and spatial variability of bedload yield in such studies has been interpreted as the result of differences in bedrock geology and/or sediment availability. Although these factors must be taken into consideration, data from Cotton Creek indicate that, in average runoff years, the temporal and spatial variability of bedload yield mainly derives from differences in hydrograph complexity. Specifically, while annual variability at a site arises from seasonal differences in meteorologic conditions during the snowmelt period, spatial variability derives from differences in basin morphometry that affect the hydrologic response to seasonal temperature fluctuations.

Although our study focuses on the connection between hydrological forcing and sediment yield in a snowmelt-dominated region, work conducted in a headwater basin of northwestern Massachusetts (Ouimet and Dethier, 2002), suggests that hydrograph variability could control fluvial sediment flux in other hydro-climatic settings.

\section{Conclusions}

The present study identifies linkages between glacial topography, channel-reach morphology, bedload sediment dynamics, and the hydrologic regime in headwater systems of the southern Columbia Mountains. In this region, subdued topography inherited from Pleistocene glaciations in conjunction with continental climate conditions do not favor mass wasting processes, so that bank undercutting and treethrow are the main agents of sediment and wood delivery to channels. Stream channels display alluvial morphologies mainly controlled by glacially-imposed local slope, wood abundance, and the availability of glacigenic sedimentary deposits. In contrast, the downstream variation of total stream power, $D_{\max }$, bankfull width and depth are insensitive to the typically stepped nature of the longitudinal profiles. These channel variates display monotonic trends across area-slope inflections so that observed DHG relations conform to those characteristic of fully-fluvial lowland systems; an indication that these streams have adjusted their geometric configuration and energy expenditure to a postglacial equilibrium state.

Contemporary fluvial sediment flux displays the characteristic trend of degradation dynamics, that is, specific sediment yield increases as a function of drainage area. This outcome implies that in this physiographic region the paraglacial fluvial response, detected across much larger systems in British Columbia (Church and Slaymaker, 1989), currently involves catchments as small as $2 \mathrm{~km}^{2}$.

The variability of the snowmelt hydrograph, to some extent dependent on slope aspect, modulates annual rates of bedload transport through the frequency of peaks over threshold discharge (nPk). A coherent pattern of high yields during rising limbs and lower yields during the corresponding falling ones across the entire freshet is consistent with the notion of limited sediment supply, released in pulses through destabilization of the surface armor layer and remobilization of material stored behind LWD structures. Examination of daily sediment yield at selected sites reveals that channel morphology exerts a primary control on the channel bed response to hydrological forcing. Consistent with the conceptual model proposed by Montgomery and Buffington (1997, 1998), riffle-pools respond like transport-limited systems, whereas step-pools and forced step-pools, behave like supply-limited ones.

Comparative morphometric analysis of Elk and Upper Cotton Creek indicates that a dominant southerly slope aspect in the former basin, imparts a faster response to meteorological fluctuations (e.g., changes of solar energy inputs), which translates into higher frequencies of peak discharges, and consistently higher annual bedload yields. The 
close dependence of annual sediment yield on hydrograph fluctuations has implications in relation to climate and/or land use/cover changes, which in turn, can amplify the variability of hydrographs in headwater streams (e.g., Alila et al., 2009; Archer et al., 2010; Fritze et al., 2011). In these regards, we think that future modeling efforts should integrate climatic, hydrologic, and geomorphic components for an improved appraisal of future scenarios.

\section{Acknowledgments}

This project was funded in part by Tembec Industries and by B.C. Forest Sciences Program research grants Y051294 and Y081214. Will Halleran (P. Geo., Apex Geoscience Consultants Ltd.) completed the detailed mapping of surficial materials under contract to Tembec (B.C. Division). The support and suggestions provided by Ellen Wohl at the outset of this research project was greatly appreciated as well as the assistance of Markus Weiler, Georg Jost, and David Gluns (B.C. Ministry of Forests) during installation of sediment monitoring sites. Dr. Abdel Azim Zumrawi (UBC, Forest Resource Management) is also thanked for helping with the stepwise regression analysis. We thank Marwan Hassan for his comments on an earlier draft of the manuscript.

\section{References}

Alila, Y., Kuras', P.K., Schnorbus, M., Hudson, R., 2009. Forest and floods: a new paradigm sheds light on age-old controversies. Water Resources Research 45, W08416. http://dx.doi.org/10.1029/2008WR007207.

Alvera, B., Garcia-Ruiz, J.M., 2000. Variability of sediment yield from a high mountain catchment, central Spanish Pyrenees. Arctic, Antarctic, and Alpine Research 32, 478-484.

Archer, D.R., Climent-Soler, D., Holman, I.P., 2010. Changes in discharge rise and fall rates applied to impact assessment of catchment land use. Hydrology Research $41,13-26$.

Benda, L., Dunne, T., 1997. Stochastic forcing of sediment routing and storage in channel networks. Water Resources Research 33, 2865-2880.

Brardinoni, F., Hassan, M.A., 2006. Glacial erosion, evolution of river long profiles, and the organization of process domains in mountain drainage basins of coastal British Columbia. Journal of Geophysical Research 111, F01013. http://dx.doi.org/10.1029/ 2005JF000358.

Brardinoni, F., Hassan, M.A., 2007. Glacially-induced organization of channel-reach morphology in mountain streams. Journal of Geophysical Research 112, F03013. http://dx.doi.org/10.1029/2006JF000741.

Brummer, C.J., Montgomery, D.R., 2003. Downstream coarsening in headwater channels. Water Resources Research 39, 1294. http://dx.doi.org/10.1029/2003WR001981.

Church, M., 1992. Channel morphology and topology. In: Calow, P., Petts, G.E. (Eds.), The River Handbook. Blackwell, Oxford, UK, pp. 126-143.

Church, M., 2006. Bed material transport and the morphology of alluvial river channels. Annual Review of Earth and Planetary Sciences 34, 325-354.

Church, M., Slaymaker, O., 1989. Disequilibrium of Holocene sediment yield in glaciated British Columbia. Nature 337, 452-454.

Church, M.A., McLean, D.G., Wolcott, J.F., 1987. River bed gravels: sampling and analysis. In: Thorne, C.R., Bathurst, J.C., Hey, R.D. (Eds.), Sediment Transport in Gravel-Bed Rivers. Wiley, New York, pp. 43-79.

Church, M., Ham, D., Hassan, M., Slaymaker, O., 1999. Fluvial clastic sediment yields in Canada: scaled analysis. Canadian Journal of Earth Sciences 36, 1267-1280.

Clague, J.J. (compiler), 1989. Quaternary geology of the Canadian Cordillera, p. 15-96. In: Fulton, R.J. (Ed.), Quaternary geology of Canada and Greenland. Geological Survey of Canada, Geology of Canada 1, 839 pp. [also Geological Society of America, The Geology of North America, K-1].

Clague, J.J., Armstrong, J.E., Mathews, W.H., 1980. Advance of the late Wisconsin Cordilleran Ice Sheet in southern British Columbia since 22,000 Yr B.P. Quaternary Research 13, 322-326.

Day, T.J., 1976. On the precision of salt dilution gauging. Journal of Hydrology 31, 293-306.

Dietrich, W.E., Kirchner, J.W., Ikeda, H., Iseya, F., 1989. Sediment supply and the development of the coarse surface layer in gravel-bedded rivers. Nature 340 215-217.

Ellis, C.R., Pomeroy, J.W., Essery, R.L.H., Link, T.E., 2010. Effects of needle-leaf forest cover on radiation and snowmelt dynamics in the Canadian Rocky Mountains. Canadian Journal of Forest Research 41, 608-620. http://dx.doi.org/10.1139/X10-227.

Emmett, W.W., 1972. The hydraulic geometry of some Alaskan streams south of the Yukon River. U.S. Geological Survey Open-File Report 72-108. . 108 pp.

Fannin, R.J., Rollerson, T., 1993. Debris flows: some physical characteristics and behaviour. Canadian Geotechnical Journal 30, 71-82

Fritze, H., Stewart, I.T., Pebesma, E., 2011. Shifts in western North American snowmelt runoff regimes for the recent warm decades. Journal of Hydrometeorology 12, 989-1006. http://dx.doi.org/10.1175/2011JHM1360.1.
Gintz, D., Hassan, M.A., Schmidt, K.H., 1996. Frequency and magnitude of bedload transport in a mountain river. Earth Surface Processes and Landforms 21, 433-445.

Gluns, D.R., 2001. Snowline pattern during the melt season: evaluation of the H60 concept. In: Toews, D.A.A., Chatwin, S. (Eds.), Watershed Assessments in the Southern Interior of British Columbia: Workshop Proceedings, March 9-10, 2000, Penticton, British Columbia: British Columbia Ministry of Forests, Research Branch, Working Paper 57, Victoria, B.C. , pp. 68-80.

Gomi, T., Sidle, R.C., 2003. Bed load transport in managed steep-gradient headwate streams of southeastern Alaska. Water Resources Research 39, 1336. http:// dx.doi.org/10.1029/2003WR002440.

Gomi, T., Sidle, R.C., Richardson, J.S., 2002. Understanding processes and downstream linkages of headwater systems. Bioscience 52, 905-916.

Grant, G.E., Swanson, F.J., Wolman, M.G., 1990. Pattern and origin of stepped-bed morphology in high gradient streams, Western Cascades, Oregon. Geological Society of America Bulletin 102, 340-352.

Hassan, M.A., Church, M., Lisle, T.E., Brardinoni, F., Benda, L., Grant, G.E., 2005. Sediment transport and channel morphology of small, forested streams. Journal of the American Water Resources Association 41, 853-876.

Heller, P.L., Beland, P.E., Humphrey, N.F., Konrad, S.K., Lynds, R.M., McMillan, M.E., Valentine, K.E., Widman, Y.A., Furbish, D.J., 2001. Paradox of downstream fining and weathering-rind formation in the lower Hoh River, Olympic Peninsula, Washington. Geology 29, 971-974.

Holland, S.S., 1964. Landforms of British Columbia: A Physiographic Outline. Department of Mines and Petroleum Resources, British Columbia. Bulletin 48, Victoria B.C., 138 pp.

Howes, D.E., Kenk, E., 1997. Terrain Classification System for British Columbia (Version 2) 1997: a system for the classification of surficial materials, landforms and geological processes of British Columbia. In: Howes, D.E., Kenk, E. (Eds.), British Columbia Ministry of Environment, Lands, and Parks, Resource Inventory Branch, Manual 10, Victoria, B.C. 102 pp.

Jackson, W.L., Beshta, R.L., 1982. A model of two-phase bed load transport in an Oregon Coast Range stream. Earth Surface Processes and Landforms 7, 515-527.

Jackson, L.E., Clague, J.J., 1991. The Cordilleran Ice Sheet: one hundred and fifty years of exploration and discovery. Géographie Physique et Quaternaire 45, 269-280.

Jakob, M., Bovis, M., Oden, M., 2005. The significance of channel recharge rates for estimating debris-flow magnitude and frequency. Earth Surface Processes and Landforms 30, 755-766. http://dx.doi.org/10.1002/esp.1188.

Jordan, P., 2002. Landslide frequencies and terrain attributes in Arrow and Kootenay Lake forest districts. In: Jordan, P., Orban, J. (Eds.), Terrain Stability and Forest Management in the Interior of British Columbia: Workshop Proceedings, Nelson, B.C., May 23-25, 2001: British Columbia Ministry of Forests, Forest Sciences Program, Victoria, B.C. Tech. Rep. 003, pp. 80-102.

Jordan, P., 2006. The use of sediment budget concepts to assess the impact on watersheds of forestry operations in southern interior of British Columbia. Geomorphology 79, 27-44. http://dx.doi.org/10.1016/j.geomorph.2005.09.019.

Jost, G., Weiler, M., Gluns, D.R., Alila, Y., 2007. The influence of forest and topography on snow accumulation and melt at the watershed-scale. Journal of Hydrology 347, 101-115. http://dx.doi.org/10.1016/j.jhydrol.2007.09.006.

Kondolf, M., Lisle, T., Wolman, G., 2003. Bed sediment measurement. In: Kondolf, M., Piegay, H. (Eds.), Tools in Fluvial Geomorphology. Wiley, Chichester, UK, pp. 347-395

Kuhnle, R.A., 1992. Fluvial transport of sand and gravel mixtures with bimodal size distributions. Sedimentary Geology 85, 17-24.

Leopold, L., Maddock, T., 1953. The hydraulic geometrv of stream channels and some physiographic implications. U.S. Geological Survey Professional Paper, 252. $57 \mathrm{pp}$.

Lisle, T.E., 1986. Stabilization of a gravel channel by large streamside obstructions and bedrock bends, Jacoby Creek, northwestern California. Geological Society of America Bulletin 97, 999-1011.

McCabe, G.J., Clark, M.P., Hay, L.E., 2007. Rain-on-snow events in the western United States. Bulletin of the American Meteorological Society 88, 319-328.

Merz, J., Doppmann, G., 2006. Measuring Mountain Stream Discharge Using the Salt Dilution Method - A Practical Guide. International Centre for Integrated Mountain Development (ICIMOD), Kathmandu. Kathmandu, 15 pp.

Montgomery, D.R., Buffington, J.M., 1997. Channel reach morphology in mountain drainage basins. Geological Society of America Bulletin 109, 596-611.

Montgomery, D.R., Buffington, J.M., 1998. Channel processes, classification, and response. In: Naiman, R.J., Bilby, R.E. (Eds.), River Ecology and Management: Lesson From the Pacific Coastal Ecoregion. Springer-Verlag, New York, pp. 13-42.

Montgomery, D.R., Foufoula-Georgiou, E., 1993. Channel network source representation using digital elevation models. Water Resources Research 29, 3925-3934.

Moog, D.B., Whiting, P.J., 1998. Annual hysteresis in bedload rating curves. Water Resources Research 34, 2393-2399.

Mueller, E.R., Pitlick, J., 2005. Morphologically based model of bed load transport capacity in a headwater stream. Journal of Geophysical Research 110, F02016. http:// dx.doi.org/10.1029/2003JF000117.

Mueller, E.R., Pitlick, J., Nelson, J.M., 2005. Variation in the reference Shields stress for bed load transport in gravelbed streams and rivers. Water Resources Research 41, W04006. http://dx.doi.org/10.1029/2004WR003692.

Nanson, G.C., 1974. Bedload and suspended-load transport in a small, steep mountain stream. American Journal of Science 274, 471-486.

Ouimet, W., Dethier, D., 2002. Modeling sediment flux from Birch Brook, an undisturbed catchment in northwestern Massachusetts. Northeastern Geology and Environmental Sciences 24, 176-184.

Pomeroy, J., Fang, X., Ellis, C., Guan, M., 2011. Sensitivity of snowmelt hydrology on mountain slopes to forest cover disturbance. University of Saskatchewan Centre for Hydrology, Report No. 10, Saskatoon, Sask., 105 pp. 
Reid, I., Frostick, L.E., Layman, J.T., 1985. The incidence and nature of bedload transport during flood flows in coarse-grained alluvial channels. Earth Surface Processes and Landforms 10, 33-44.

Ryan, S.E., Dixon, M.K., 2008. Spatial and temporal variability in stream sediment loads using examples from the Gros Ventre Range, Wyoming, USA. In: Habersack, H., Piegay, H., Rinaldi, M. (Eds.), Gravel-Bed Rivers VI: From Process Understanding to River Restoration. Elsevier, Amsterdam, pp. 387-407.

Ryan, S.E. Porth, LS., 2007. A tutorial on the piecewise regression approach applied to bedload transport data. U.S. Department of Agriculture, Forest Service, Rocky Mountain Research Station General Technical Report RMRS-GTR-189. Fort Collins, CO., $41 \mathrm{pp}$.

Ryan, S.E., Porth, L.S., Troendle, C.A., 2005. Coarse sediment transport in mountain streams in Colorado and Wyoming, USA. Earth Surface Processes and Landforms 30, 269-288. http://dx.doi.org/10.1002/esp.1128.

Ryder, J.M., 1981. Biophysical resources of the East Kootenay area. Generalized Terrain, British Columbia. British Columbia Ministry of Environment. 250,000.82 G, J.

Ryder, J.M., Fulton, R.J., Clague, J.J., 1991. The Cordilleran Ice Sheet and the glacial geomorphology of southern and central British Columbia. Géographie Physique et Quaternaire 45, 365-377.

Sidle, R.C., 1988. Bed load transport regime of a small forest stream. Water Resources Research 24, 207-218.

Sterling S.M. Church, M. 2002. Sediment trapping characteristics of a pit trap and the Helley-Smith sampler in a cobble gravel bed river. Water Resources Research 38, 1144, 11pp. http://dx.doi.org/10.1029/2000WR000052.

Swanson, F.J., Fredricksen, R.L., McCorison, F.M., 1982. Material transfer in a western Oregon forested watershed. Analysis of Coniferous Forest Ecosystems in the Western United States, US/IBP Synthesis Series. Huchinson Ross Publ., Stroudsburg, Penn, pp. 233-266.
Swanson, F.J., Johnson, S.L., Gregory, S.V., Acker, S.A., 1998. Flooding: natural and managed. Bioscience 48, 681-689.

Troendle, C.A. Olsen, W.K., 1994. Potential effects of timber harvest and water management on streamflow dynamics and sediment transport. In: Covington, W.W., DeBano, D.F., (Coords.) Sustainable Ecological Systems: Implementing an Ecological Approach to Land Management, July 12-15, 1993, Flagstaff, AZ. U.S. Forest Service General Technical Report RM-247, 34-41.

Warburton, J 1990 Comparison of bed load yield estimates for a glacial meltwater stream. Proceedings of two Lausanne Symposia, August 1990. Hydrology in Mountainous Regions. I - Hydrological Measurements; the Water Cycle: IAHS Publication, 193, pp. 315-323.

Whitaker, A., Alila, Y., Beckers, J., 2002. Evaluating peak flow sensitivity to clear-cutting in different elevation bands of a snowmelt-dominated mountainous catchment. Water Resources Research 38, 1172. http://dx.doi.org/10.1029/2001WR000514.

Whitaker, A., Alila, Y., Beckers, J., Toews, D., 2003. Application of the distributed hydrology soil vegetation model to Redfish Creek British Columbia: model evaluation using internal catchment data. Hydrological Processes 17, 199-224.

Whiting, P.J., Stamm, J.F., Moog, D.B., Orndorff, R.L., 1999. Sediment-transporting flows in headwater streams. Geological Society of America Bulletin 111, 450-466.

Wohl, E., 2004. Limits of downstream hydraulic geometry. Geology 32, 897-900.

Wohl, E., 2010. Mountain rivers revisited. Water Resources Monograph, 19. American Geophysical Union Press. 573 pp.

Wohl, E.E., Wilcox, A., 2005. Channel geometry of mountain streams in New Zealand. Journal of Hydrology 300, 252-266. 